Review

\title{
Obesity-linked diabetes in the Arab world: a review
}

\author{
B. Abuyassin ${ }^{7}$ and I. Laher ${ }^{1}$
}

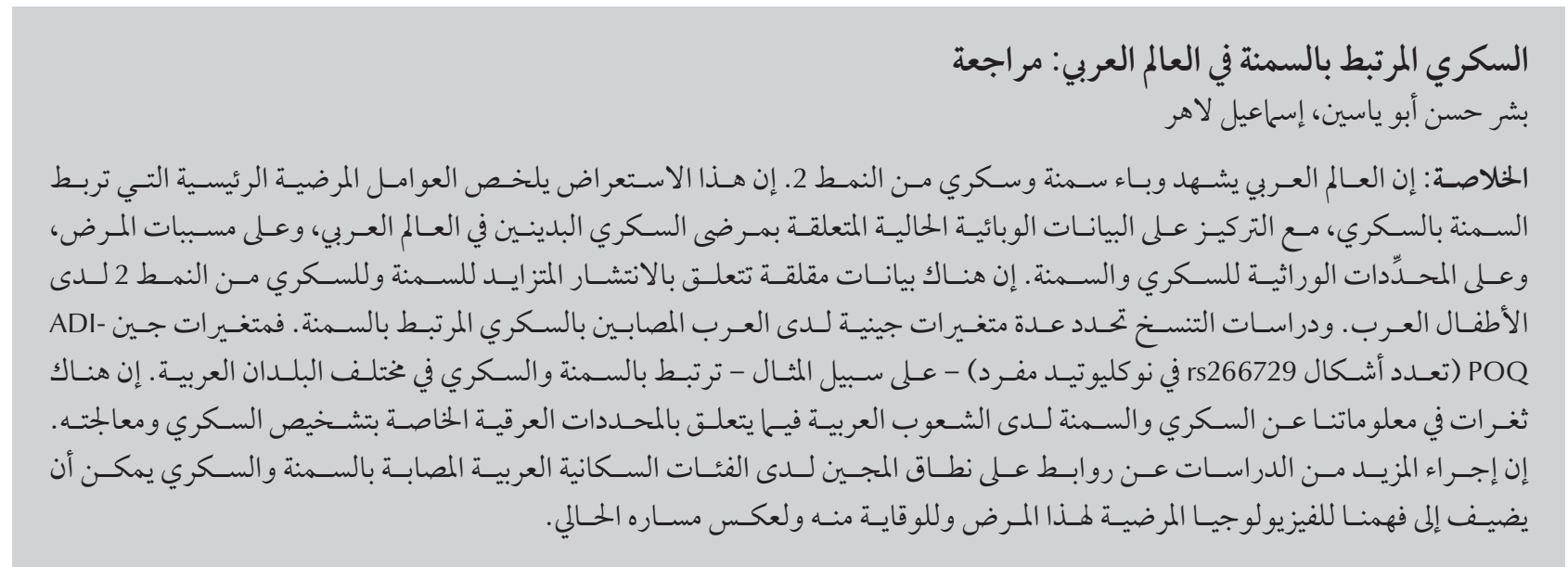

ABSTRACT The Arab world is experiencing an epidemic of obesity and type 2 diabetes mellitus. This review summarizes the major pathological factors linking obesity to diabetes, focussing on current epidemiological data related to obese diabetic patients in the Arab world, the etiology of the disease and the genetic determinants of diabetes and obesity. There are alarming data related to the rising prevalence of obesity and type 2 diabetes mellitus in children of Arab ethnicity. Replication studies identify several genetic variants in Arabs with obesitylinked diabetes. For example, variants of the $A D I P O Q$ gene (the rs266729 single-nucleotide polymorphism) are associated with obesity and diabetes in various Arab countries. Gaps exist in our information about diabetes and obesity in Arab populations in relation to ethnic-specific cut-off points for diagnosis and treatment of diabetes. Further genome-wide association studies in obese and diabetic Arab populations could add to our understanding of the pathophysiology, prevention and reversal of this disease.

\section{Diabète lié à l'obésité dans le monde arabe : analyse}

RÉSUMÉ Le monde arabe connait une épidémie d'obésité et de diabète de type 2. La présente analyse récapitule les facteurs pathologiques majeurs liant l'obésité au diabète, en se concentrant sur les données épidémiologiques actuelles relatives aux patients diabétiques obèses dans le monde arabe, l'étiologie de la maladie et les déterminants génétiques du diabète et de l'obésité. Les données relatives à l'augmentation de la prévalence de l'obésité et du diabète de type 2 chez les enfants appartenant à un groupe ethnique arabe sont alarmantes. Des études similaires ont identifié plusieurs variantes génétiques chez les Arabes atteints de diabète lié à l'obésité. Par exemple, des variantes du gène $A D I P O Q$ (le polymorphisme du nucléotide simple rs266729) sont associées à une obésité et un diabète dans plusieurs pays arabes. Des lacunes existent dans nos informations sur le diabète et l'obésité dans les populations arabes concernant les seuils propres aux ethnies pour le diagnostic et le traitement du diabète. Des études d'association pangénomique supplémentaires dans des populations arabes diabétiques et obèses pourraient accroître notre compréhension de la physiopathologie et de la prévention et permettraient de faire reculer la maladie. 


\section{Introduction}

The population of Arab countries comprise nearly 370 million people from 22 different countries living in an area of 14 million $\mathrm{km}^{2}$ and sharing a common language. Recent statistics indicate that nearly $50 \%$ of the total Arab population are less than 25 years of age. A major health issue in the Arab world is the rising prevalence of uncontrolled weight gain. This is reflected in increases in the prevalence of several diseases, particularly type 2 diabetes mellitus (T2DM), the prevalence of which has also increased dramatically during the last 2 decades. T2DM has become a source of suffering to both patients and their caregivers. In addition, it presents a great challenge to Arab governments due to the large economic burden of diabetes in terms of cost of treatment, management of complications, disability and loss of productivity (1-5).

Obesity constitutes a large component of the pathogenesis of T2DM through various mechanisms. Obese diabetic patients have a significantly higher risk of microvascular complications and greater mortality $(6,7)$. In addition, obesity worsens the prognosis of T2DM (8). This review summarizes the major pathological factors linking obesity to diabetes, focussing on current epidemiological data related to obese diabetic patients in the Arab world and the etiology of the disease. Finally, we will address some of the research needed to reach a better understanding of the disease that could inform efforts to control obesity-linked T2DM in Arab populations.

\section{Search methodology}

We undertook a search of the medical literature using the PubMed, Embase and Ovid databases for articles published in English language between 1980 and 2014, and included the following keywords: diabetes, obesity,
Arab world, epidemiology, etiology and genetics, or their corresponding $\mathrm{MeSH}$ term synonyms. A total of 6055 papers were identified and screened by title and/or abstract. To ensure that we included the highest number of epidemiological studies from each country, we did not set any limitations on the study design in our exclusion criteria. However, animal or genetic studies, studies not relevant to T2DM or obesity, studies on the complications of diabetes or the effects of treatment, and non-primary data such as review articles or adherence studies were excluded (Figure 1). A total of 122 studies were considered for the article and were reviewed in full. Among these, 41 studies were excluded because the samples were not representative. Table 1 lists the Arab countries from which studies reporting the prevalence of obesity-linked type 2 diabetes mellitus were identified and analysed for this review. In addition, we included 4 studies concerning Arab immigrants in different countries not listed in Table 1.

\section{Pathological mechanisms}

An increased body mass index (BMI) above the normal range (18.5-24.9 kg/ $\mathrm{m}^{2}$ ) is associated with a greater risk of T2DM. In fact $90 \%$ of T2DM is attributed to excess weight (9). Several studies have found that the risk of diabetes increased by $>20$-fold for females and 10-fold for males when BMI is between $30-35 \mathrm{~kg} / \mathrm{m}^{2}(10,11)$. Several biological factors can influence insulin sensitivity; for example, pregnancy and ageing decrease sensitivity to insulin, while physical activity increases it. Obesity and insulin resistance leads to T2DM, particularly when the pancreas is unable to compensate for reduced insulin sensitivity (12). This usually occurs with obese patients, in whom certain products of adipose tissue are increased, including non-esterified fatty acids (NEFA), glycerol and pro-inflammatory cytokines.

\section{Lipotoxicity}

Lipotoxicity is central to our understanding of the role of excessive fat deposition in promoting insulin resistance, particularly in central obesity, which is mainly attributed to the accumulation of intra-abdominal (visceral) fat (13). Storage of triglycerides is promoted by persistent excessive caloric intake, leading to a state of a positive energy balance. Triglycerides increase the proportion of adipocytes that are hypertrophied, becoming more resistant to the antilipolytic effects of insulin, resulting in the release of higher amounts of fatty acids into the circulation.

\section{Non-esterified fatty acids}

Another critical factor involved in obesity-related insulin resistance is the release of non-esterified fatty acids (NEFA) by adipocytes. Circulating levels of NEFA are elevated in the circulation, predominantly by an obesity-driven enlargement of abdominal subcutaneous adipose tissue (14). Insulin resistance develops within hours of elevation of NEFA in the plasma, while treatment with antilipolytics reduces NEFA levels and significantly improves insulin sensitivity $(12,15)$. Circulating NEFA reduce glucose uptake by adipocytes and the liver, and further promote hepatic glucose output to cause hyperglycaemia (16). In addition, metabolites of NEFA impede insulin-stimulated glucose transport in muscle and inhibit the normal suppression of gluconeogenesis (13). Protein kinase C isoforms are also activated by fatty acid metabolites such as diacylglycerol and ceramides, resulting in a detrimental effect on insulin signalling. Moreover, the energy produced by fatty acid oxidation is utilized by the liver for gluconeogenesis which then further increases blood glucose levels (13). 


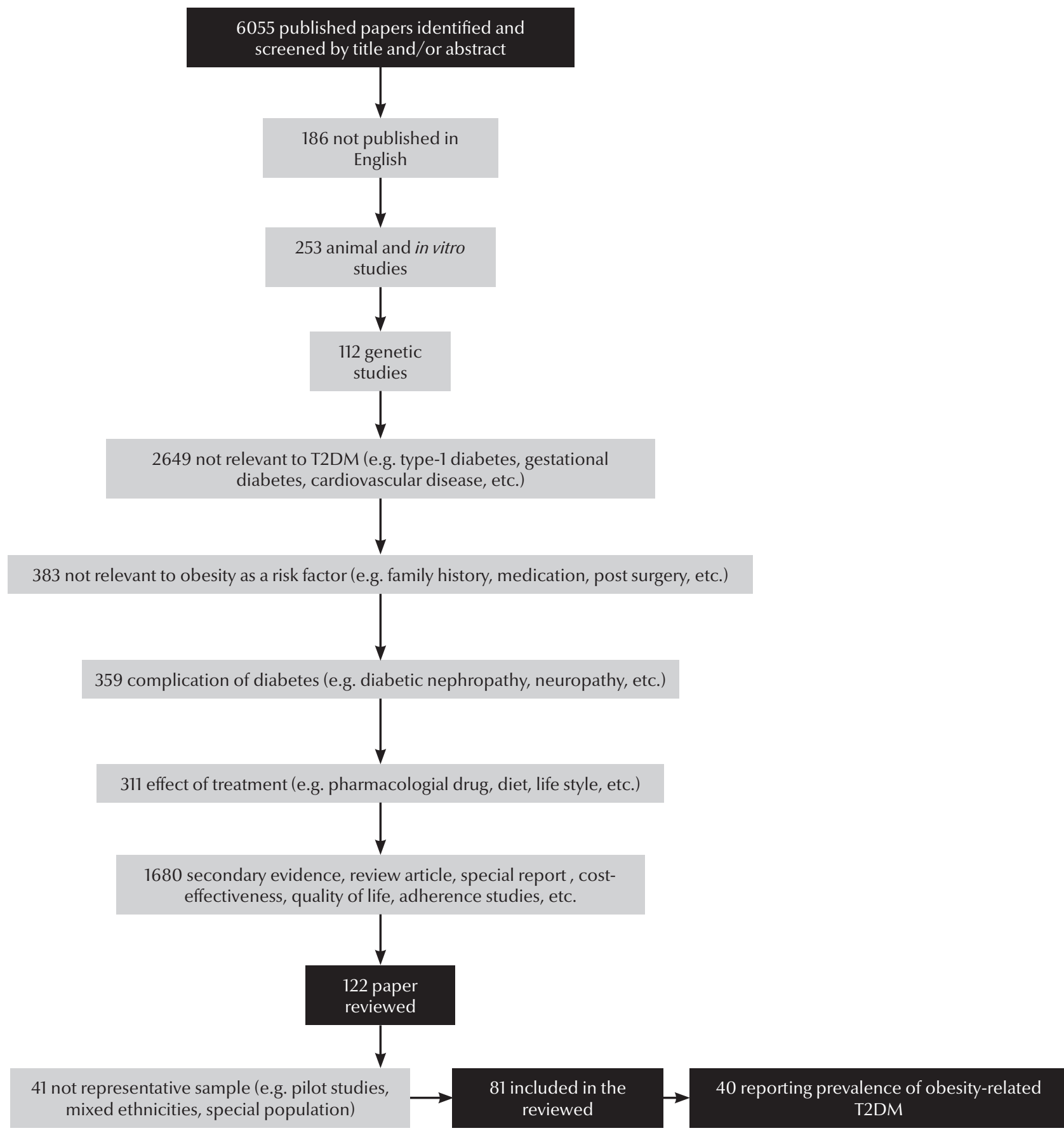

Figure 1 Number of papers examined and excluded from the literature review (T2DM = type 2 diabetes mellitus)

\section{Adipocyte hormones}

Adipose tissue releases several protein hormones that regulate energy homeostasis and lipid and carbohydrates metabolism (17). Adiponectin, leptin, resistin and other hormones are key in developing insulin resistance and T2DM in obesity. Plasma levels of adipocyte products increase as a result of enlarged adipose tissues in obesity, with the exception of adiponectin and the newly identified visceral fat proteins omentin and vaspin $(18,19)$. Table 2 summarizes the major roles of different protein hormones in obese subjects.

Adiponectin functions primarily by counteracting insulin resistance. Therefore, it constitutes an essential natural defensive mechanism against
T2DM and other cardiovascular diseases, mainly through regulating carbohydrates and fat catabolism in liver and skeletal muscles (20). Increased adipocyte deposition leads to a marked reduction in adiponectin levels in obese diabetic patients (21). Furthermore, adiponectin levels negatively correlate with insulin resistance $(22,23)$. Adiponectin enhances insulin sensitivity 


\begin{tabular}{|c|c|c|c|c|}
\hline \multirow[t]{2}{*}{ Country } & \multirow{2}{*}{$\begin{array}{c}\text { Studies found } \\
\text { No. }\end{array}$} & \multirow{2}{*}{$\begin{array}{c}\text { Studies } \\
\text { reviewed } \\
\text { No. }\end{array}$} & \multicolumn{2}{|c|}{ Studies analysed } \\
\hline & & & No. & Reference \\
\hline Algeria & 123 & 3 & 0 & - \\
\hline Bahrain & 103 & 3 & 1 & (107) \\
\hline Comoros & 6 & 1 & 0 & - \\
\hline Djibouti & 8 & 1 & 0 & - \\
\hline Egypt & 1129 & 8 & 3 & (108), (109), (110) \\
\hline Iraq & 134 & 5 & 2 & (112), (113) \\
\hline Jordan & 226 & 7 & 1 & (114) \\
\hline Kuwait & 509 & 10 & 4 & (52), (115), (116), (117) \\
\hline Lebanon & 325 & 9 & 2 & (118), (119) \\
\hline Libya & 78 & 4 & 1 & (120) \\
\hline Mauritania & 9 & 1 & 0 & - \\
\hline Morocco & 224 & 7 & 1 & (121) \\
\hline Oman & 226 & 5 & 1 & (122) \\
\hline Palestine & 59 & 4 & 2 & (123), (124) \\
\hline Qatar & 231 & 7 & 2 & (58), (125) \\
\hline Saudi Arabia & 1534 & 20 & 10 & $\begin{array}{l}\text { (50), (49), (126), (127), } \\
\text { (128), (129), (130), (131), } \\
\text { (132), (133) }\end{array}$ \\
\hline Somalia & 20 & 1 & 0 & - \\
\hline Sudan & 160 & 6 & 2 & (44), (134) \\
\hline Syrian Arab Republic & 38 & 3 & 1 & (135) \\
\hline Tunisia & 443 & 5 & 1 & (136) \\
\hline United Arab Emirates & 419 & 7 & 3 & (43), (53), (111) \\
\hline Yemen & 51 & 5 & 3 & (137), (138), (139) \\
\hline Total & 6055 & 122 & 40 & \\
\hline
\end{tabular}

primarily by increasing fatty acid oxidation and inhibition of hepatic glucose production (24).

Plasma levels of adiponectin are reduced secondary to obesity as shown by studying people from different countries. Measurements of serum adiponectin levels in 33 metabolically healthy and 56 metabolically unhealthy Saudi Arabians showed that the average serum adiponectin level in metabolically unhealthy subjects was $5.9 \mu \mathrm{g} / \mathrm{mL}$ versus $8 \mu \mathrm{g} / \mathrm{mL}$ in control subjects $(P<$ $0.0001)$ (25). Another cross-sectional study from the United Arab Emirates (UAE) examined the correlation between the components of metabolic syndrome and body weight in $69 \mathrm{fe}$ males categorized as either as lean, overweight or obese (26). Adiponectin levels correlated negatively with BMI $(r=-0.44, P<0.05)$. In addition, insulin resistance was significantly higher in obese subjects. Likewise, in Qatar adiponectin levels were measured in 64 obese diabetic, 61 obese non-diabetic and 72 control people (27). Mean serum adiponectin levels were $7.21,10.81$ and $12.83 \mu \mathrm{g} / \mathrm{mL}$ in obese diabetic, obese non-diabetic and control subjects respectively $(P<0.05)$. Another study measured serum levels of adiponectin in 50 obese and 30 lean children from Egypt (28). The mean serum adiponectin level in obese children was $8.7 \mu \mathrm{g} /$ $\mathrm{mL}$, while lean children had a level of $13.4 \mu \mathrm{g} / \mathrm{mL}(P<0.001)$.

Leptin is another hormone that is primarily secreted by adipose tissue and which acts through the hypothalamus to suppress food intake and to increase energy expenditure (17). Leptin increases insulin sensitivity and muscle fatty acid oxidation (17), whereas deficiencies of leptin or its receptors results in obesity and other metabolic disorders (29). Unlike adiponectin, plasma levels of leptin correlate directly with adipose tissue mass and obesity. However, failure of leptin to exert its weight-loss actions in obese subjects with hyperleptinaemia is attributed to leptin resistance, which is also a risk factor for obesity $(29,30)$. In addition, leptin levels significantly correlate with insulin resistance $(31,32)$. Nevertheless, it has been proposed that the leptin-to-adiponectin ratio potentially constitutes a useful measure of insulin resistance, given that obesity is largely associated with high leptin and 


\begin{tabular}{|c|c|c|c|}
\hline Adipokine & Physiological role & Effect in T2DM & References \\
\hline Adiponectin & $\begin{array}{l}\text { Insulin resistance } \\
\text { Inflammation }\end{array}$ & $\begin{array}{l}\text { Inhibition of hepatic glucose production } \\
\text { Increased fatty acid oxidation } \\
\text { Stimulation of glucose uptake in skeletal } \\
\text { muscle } \\
\text { Stimulation of insulin secretion } \\
\text { Higher insulin sensitivity }\end{array}$ & $\begin{array}{l}\text { (18), (41), (140), } \\
(141)\end{array}$ \\
\hline Leptin & $\begin{array}{l}\text { Regulation of food intake } \\
\text { Increased energy expenditure }\end{array}$ & $\begin{array}{l}\text { Higher insulin sensitivity } \\
\text { (Leptin resistance associated with } \\
\text { obesity) }\end{array}$ & (18), (142) \\
\hline Resistin & $\begin{array}{l}\text { Insulin resistance } \\
\text { Inflammation }\end{array}$ & $\begin{array}{l}\text { Reduced insulin sensitivity } \\
\text { Alteration in glucose metabolism } \\
\text { Inhibition of insulin signalling }\end{array}$ & (18), (19), (143) \\
\hline Visfatin & Insulin resistance & (Not fully explained in humans) & $(18),(40)$ \\
\hline Omentin & Insulin resistance & $\begin{array}{l}\text { Enhancement of insulin-stimulated } \\
\text { glucose transport }\end{array}$ & (144), (141) \\
\hline Vaspin & Insulin resistance & (Not fully explained in humans) & (18), (141) \\
\hline Retinol-binding protein-4 & $\begin{array}{l}\text { Insulin resistance } \\
\text { Lipid metabolism }\end{array}$ & $\begin{array}{l}\text { Inhibition of insulin signalling in } \\
\text { adipocytes by inducing inflammation } \\
\text { through activation of pro-inflammatory } \\
\text { cytokines }\end{array}$ & (18), (145) \\
\hline
\end{tabular}

low adiponectin levels. Interestingly, the leptin-to-adiponectin ratio negatively correlates with insulin sensitivity in nondiabetic White individuals (33).

Resistin is an adipose-tissue-derived peptide hormone discovered in 2001 and shown to be involved in the link between insulin resistance and obesity (34). This animal study revealed significant reductions in the levels of circulating resistin by the anti-diabetic drug rosiglitazone. Moreover, administration of recombinant resistin increased plasma glucose levels and, conversely, neutralizing circulating resistin reduced glucose levels and improved insulin resistance. Circulating resistin is controlled by several substances including thiazolidinediones, insulin, tumour necrosis factor alpha (TNF- $\alpha$ ) and growth hormones (35). Data on resistin-related insulin resistance in obesity are contradictory, since several studies reported a significant association between resistin and insulin resistance in obese subjects $(36,37)$, whereas other studies were unable to confirm this $(38,39)$.

Visfatin is an adipocyte protein that was first reported in 2005, and derives its name from its high expression levels in visceral fat. The pathological role of visfatin in insulin resistance is yet to be examined in full. However, a recently published meta-analysis reported significant increases in circulating visfatin levels in overweight and obese subjects (40). Moreover, visfatin concentrations significantly increase in patients with T2DM where there is also a significant association between visfatin and insulin resistance. Other important factors in obesity-related T2DM are the release of pro-inflammatory cytokines by adipocytes; however their pathological role in inducing insulin resistance and diabetes is unclear. Both fasting plasma levels of TNF- $\alpha$ and dysregulation of interleukin-6 activity are associated with increased insulin resistance and T2DM (41).

\section{Epidemiology}

Obese diabetic patients have a worse prognosis in terms of lifetime disease outcomes when compared with nonobese diabetics and this is concerning when we consider that the prevalence of obesity and T2DM has reached alarming levels in the Arab world (42-44). While there are many similarities between the countries, they differ significantly in terms of the socioeconomic determinants of health. These differences impact the prevalence of obesity and diabetes across the Arab countries.

\section{Adults}

The global population of overweight and obese individuals in the world reached 2.1 billion in 2013 (45). The worldwide prevalence of obesity has almost doubled since 1980, with obesity rates tripling in developing countries during the past 20 years (46). Furthermore, the global number of adults with diabetes was estimated to increase from 171 million in the year 2000 to 366 million by 2030 .

The Arab population are not immune from the worldwide trend in obesity. Several studies have addressed the prevalence of obesity and diabetes in different Arab countries (Table 3). Saudi Arabia has the 5th highest rate of diabetes worldwide, with $20 \%$ of the population being affected (47). A study of 17232 Saudi people in a community-based national epidemiological health survey of the prevalence of obesity reported that nearly $36 \%$ of 


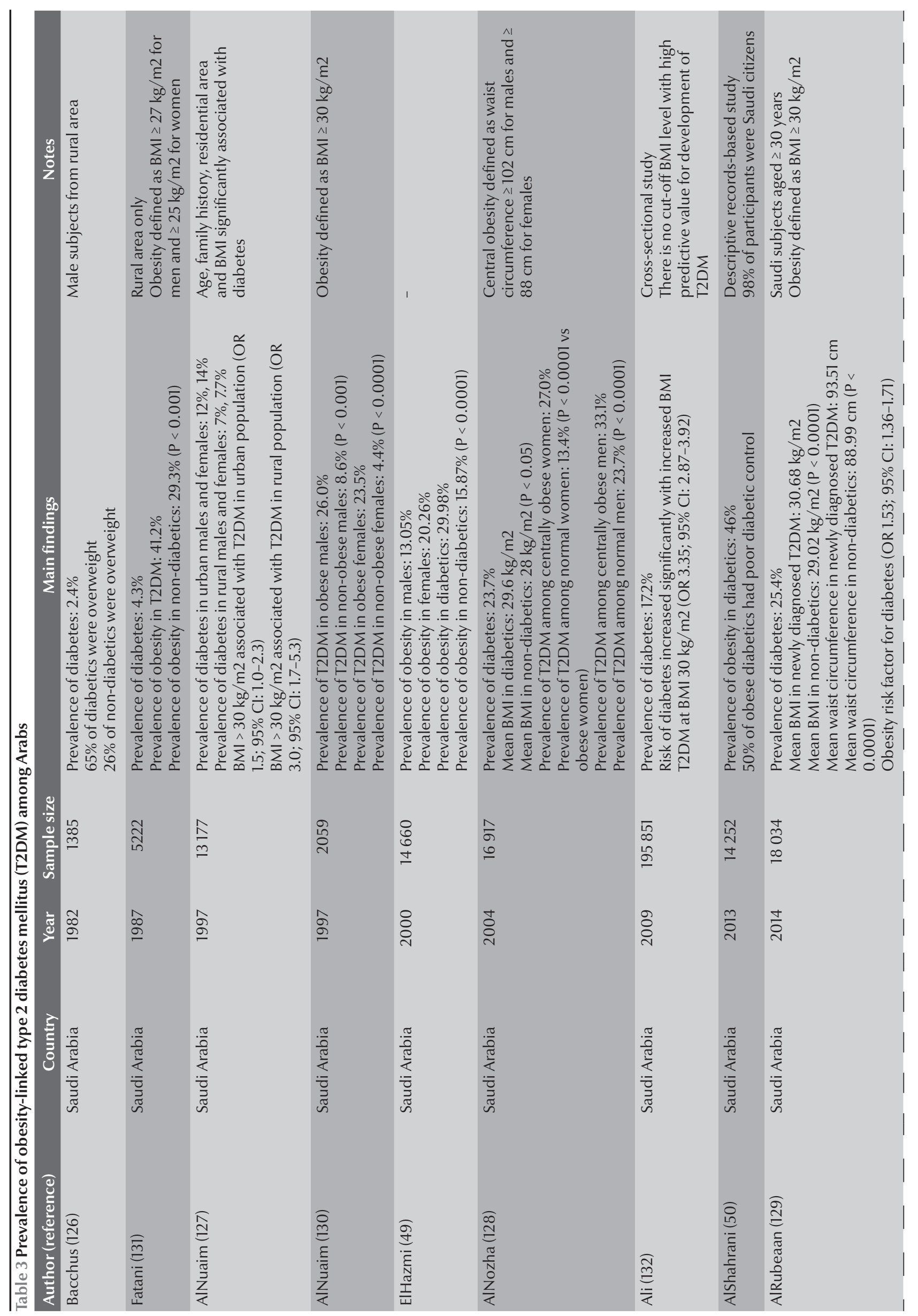




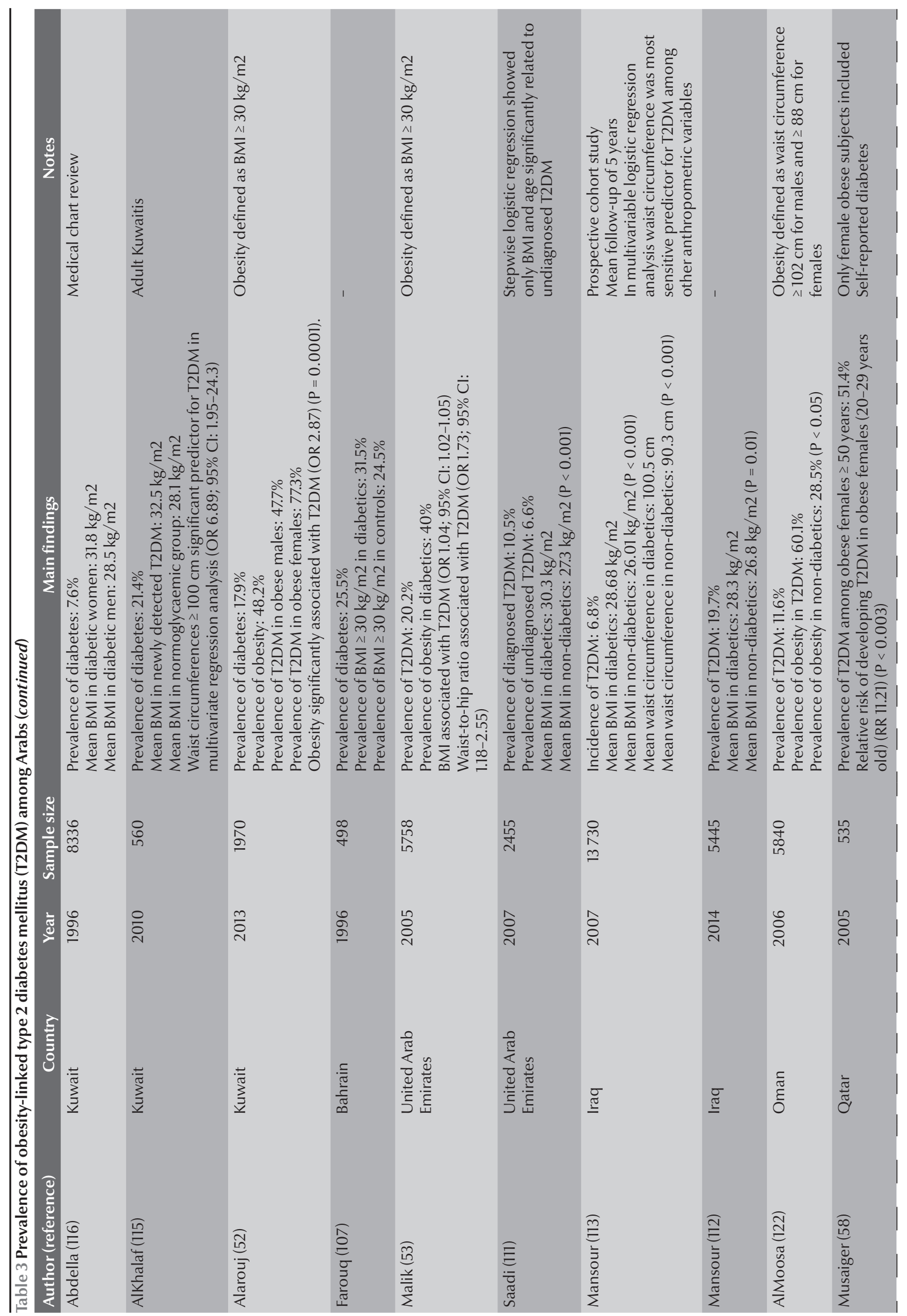




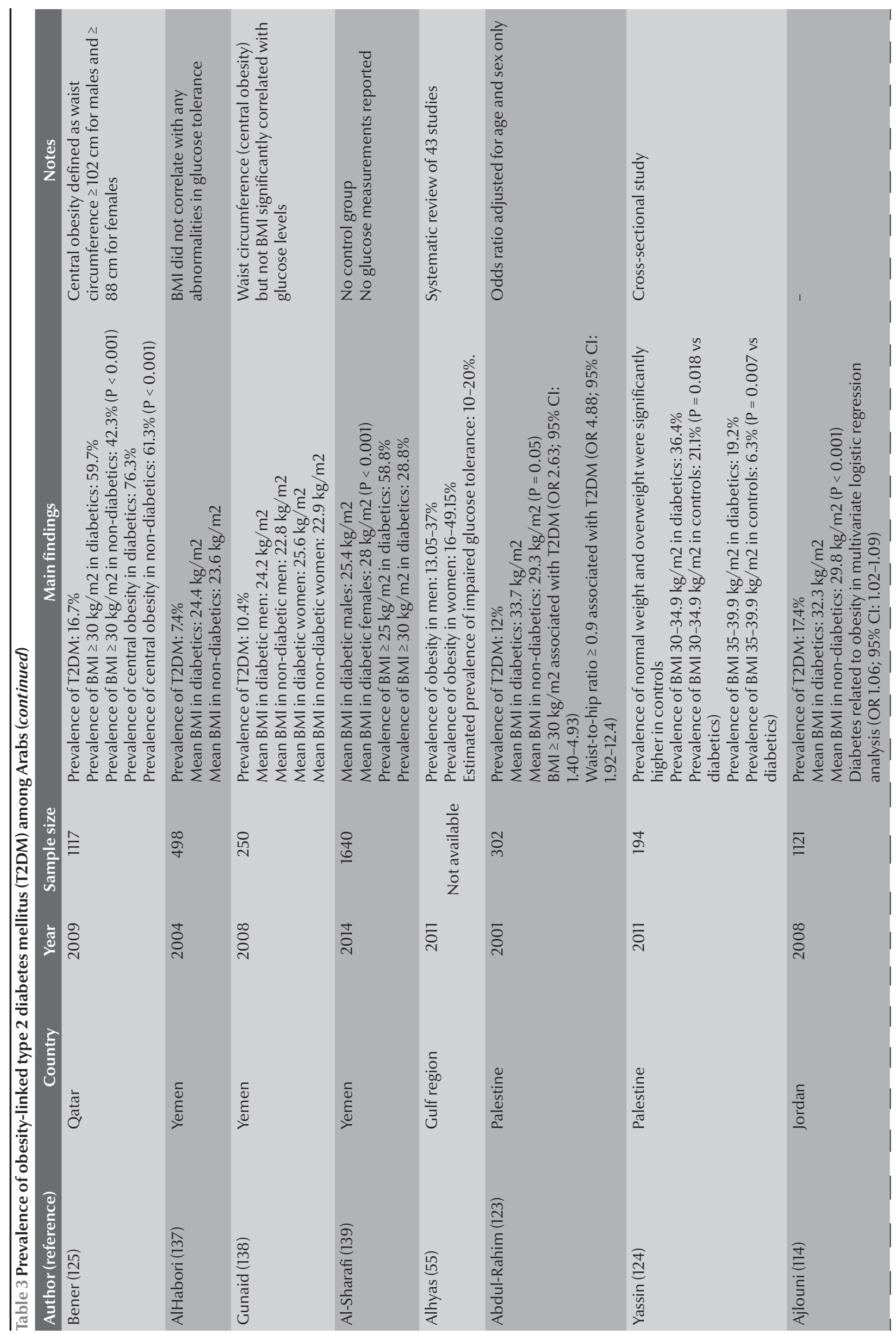




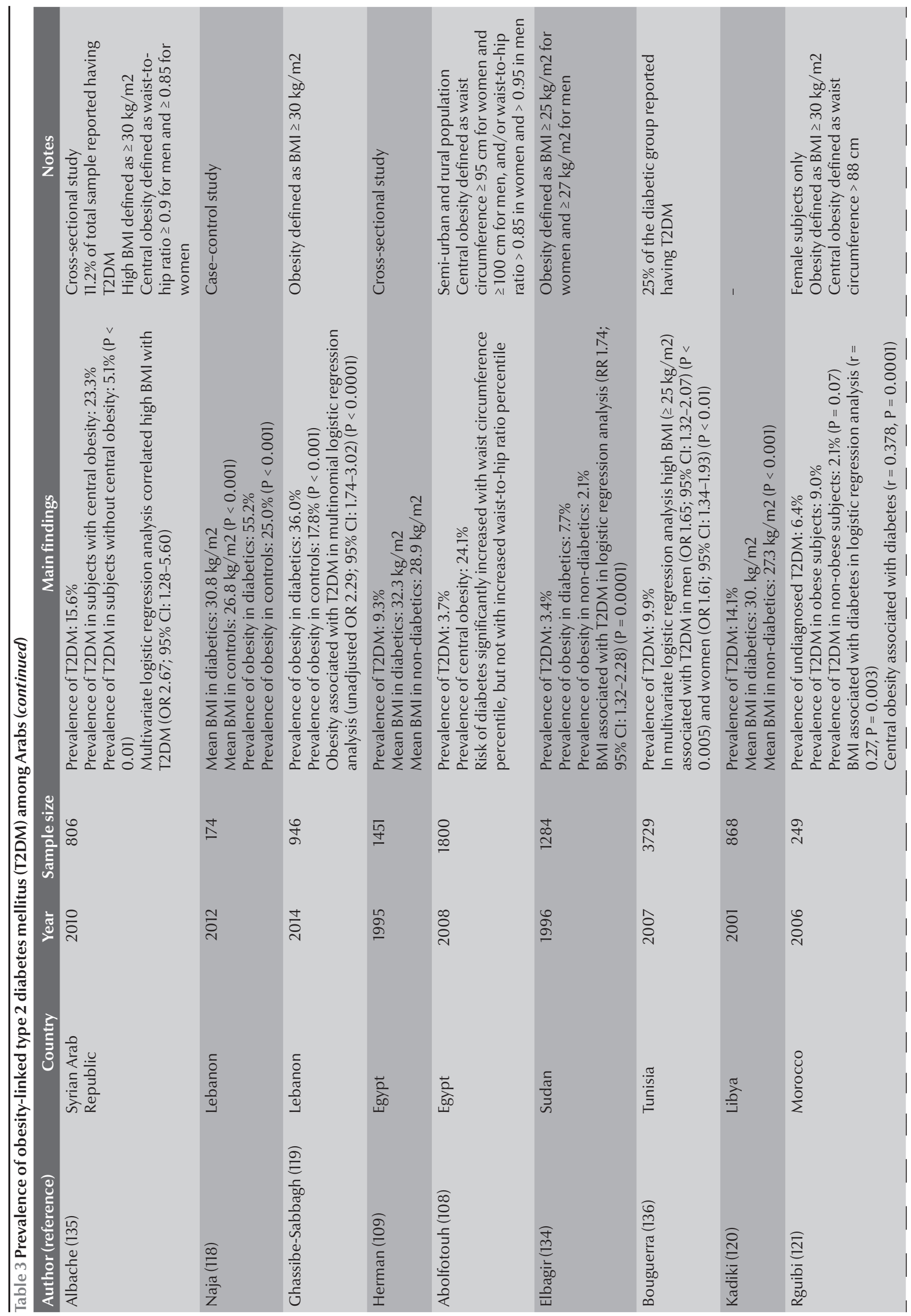




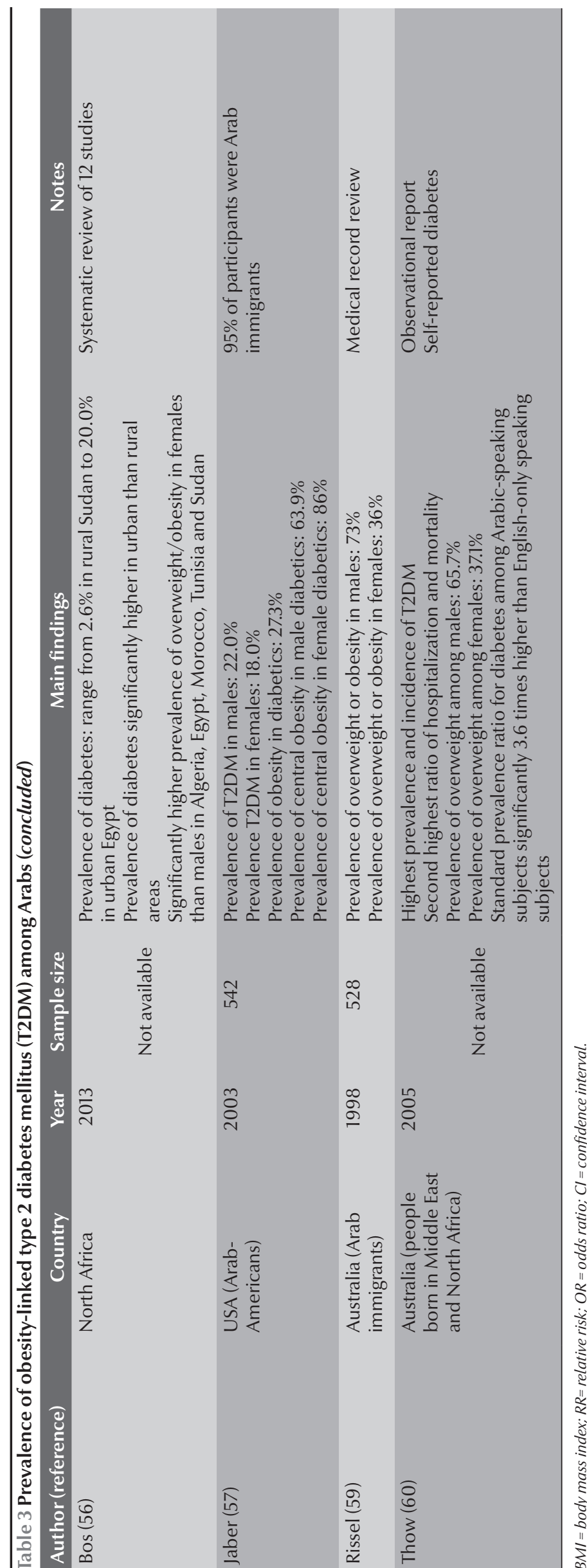

the population were obese, with the prevalence being greater in females (44\%) than in males (26\%) (48).

Another study in Saudi Arabia in 2000 reported the prevalence of obesity and diabetes in 14660 individuals (49). Obesity was monitored according to the World Health Organization (WHO) classification: underweight $(\mathrm{BMI}<18.5$ $\mathrm{kg} / \mathrm{m}^{2}$ ), normal weight (BMI 18.5-24.9 kg/m²), overweight (BMI $25-29.9 \mathrm{~kg} / \mathrm{m}^{2}$ ) and obesity $\left(\mathrm{BMI} \geq 30 \mathrm{~kg} / \mathrm{m}^{2}\right)$. Overall, $13.1 \%$ of male and $20.3 \%$ of female patients were obese. The total prevalence of obesity in the diabetic group was $30 \%$, while only $16 \%$ of the non-diabetic group were obese $(P<0.0001)$.

A later study reported on obesity levels in 14252 diabetic patients in the Aseer region of Saudi Arabia (50). The majority (98\%) of the study group were Saudi citizens. Based on the WHO classification of obesity, the study revealed that $46 \%$ of the diabetic patients were obese. Nearly $50 \%$ of obese diabetic patients had poor diabetic control (fasting blood glucose $>179 \mathrm{mg}$ / $\mathrm{dL}$ on the last 2 readings), while only $21 \%$ of these obese diabetic patients had good diabetic control (fasting blood glucose $<130 \mathrm{mg} / \mathrm{dL}$ ).

The prevalence of diabetes in Kuwait reached $23 \%$ in 2013 according to reports from the International Diabetes Federation (51). The first national survey assessing levels of diabetes and other cardiovascular risk factors in Kuwaiti adults was performed by Alarouj et al. (52). They found that $48 \%$ were obese and $18 \%$ were diabetic. Nearly $48 \%$ of obese male adults were diabetic compared with $77 \%$ of female obese adults. There was a significant association between obesity and diabetes, with an odds ratio of $2.87(P<0.001)$.

In the UAE, the prevalence of obesity and diabetes is similar to other countries in the Arab Gulf region. The results of a national survey aimed at determining the prevalence of diabetes and its associated factors in 5758 adults in the UAE revealed that $20 \%$ had diabetes, of whom nearly $40 \%$ were obese. (53). A cross-sectional analysis of 602 individuals from different ethnic groups in the UAE studied the impact of several factors on T2DM (54). People with Middle Eastern ancestry had the highest prevalence of T2DM (42\%) compared to Asian, European, African and Americans. Moreover, obesity (BMI > $30 \mathrm{~kg} /$ $\mathrm{m}^{2}$ ) was the most significant factor contributing 
to T2DM among all participants $(P<$ $0.01)$.

A recent systematic review of 33 studies summarized multiple risk factors for diabetic patients in the Arab Gulf region (55). These studies reported prevalence rates of obesity between $13-37 \%$ in men and $16-49 \%$ in women. In addition, it was found that $10-20 \%$ of subjects in the region also had impaired fasting glucose.

A recent systematic review illustrates the rising prevalence of diabetes and its complications in North Africa (56). During the period January 1990 to July 2012, the prevalence of diabetes ranged from 3\% in rural Sudan to 20\% in urban Egypt.

Of note is that obesity and diabetes remains a significant concern for Arab migrants to other parts of the world. The prevalence of T2DM was examined among 542 Arab-Americans in Michigan in the United States of America (USA), 95\% of whom were immigrants (57). Nearly a quarter of male (22\%) and nearly a fifth of female (18\%) study participants were diabetic. Of these diabetic patients, $27 \%$ were obese and, importantly, there was a significant association between central obesity and diabetes, whereby $64 \%$ of male and $86 \%$ of female diabetic patients also had central obesity.

Most studies report a higher incidence of both obesity and diabetes among females in the Arab population. The relationship between obesity and several chronic diseases was evaluated in different age groups in 535 Qatari women (58). The prevalence of diabetes reached $51 \%$ in obese females aged 50 years and above, and the risk of developing diabetes was extremely high, with a relative risk of $11.21(P<0.003)$ in obese female women aged 20-29 years old.

A study of Arab migrants to Australia reported similar data to those in the USA. Cardiovascular risk factors were examined in 528 Arabic-speaking patients in Sydney (59). Large numbers of male (73\%) and female (36\%) patients were found to be either overweight or obese. Another study of Arab immigrants to Australia reported that those born in the Middle East and North Africa had the highest prevalence and incidence of T2DM. Their data revealed that men born in the Middle East or North Africa were 3.6 times more likely to develop diabetes than Australian-born men $(P=0.05)(60)$.

\section{Adolescents and children}

Genetic factors and family history play major roles in the occurrence of diabetes in Arab populations. However, obesity remains the primary risk factor for developing T2DM. The increasing number of diabetics in the younger age groups is related to the rise of obesity among children and adolescents in Arab populations. Table 4 summarizes the latest findings on obese diabetic Arab children and adolescents.

The first reported case of T2DM in children in the United Kingdom was in youths of Arab, Pakistani and Indian origins (42). This occurred in 8 children aged 9-16 years who were overweight and with family histories of obesity-linked diabetes. A study of 96 children diagnosed with diabetes between 1999-2001, 11 of whom were aged 8-18 years old and diagnosed with T2DM in Al-Ain in the UAE indicated that obesity and overweight was prevalent in this group (8 out of 11 cases), and affecting predominantly females ( 10 out of 11 cases) (43). Nine out of the 11 children were of Arab ethnicity (although all the children had resided in the UAE for a minimum of 3 years prior to the diagnosis of T2DM). A recently performed retrospective hospital-based cross-sectional study assess the prevalence of T2DM among children and adolescents in Khartoum, Sudan (44). Among 958 children registered at the diabetes referral centre, 38 were diagnosed with T2DM, the majority of whom were aged 11-18 years. The female to male ratio was 1.2: 1 and obesity was present in 29 out of 38 children with T2DM, with another 8 children being overweight. The majority (32/38) of children with $\mathrm{T} 2 \mathrm{DM}$ in this report were from tribes of Arab origin.

These data about the occurrence of diabetes in children and adolescents were also confirmed in other crosssectional studies that reported a very high prevalence of overweight and obesity among Arab male adolescents, ranging from 13\% in Algeria to $60 \%$ in Kuwait $(61,62)$. A similar prevalence of obesity and overweight occurred in females, with $16 \%$ of Palestinian and $41 \%$ of Kuwaiti adolescent girls being affected.

\section{Etiology}

A number of studies have examined some of the reasons underlying the rise in obesity in Arab populations (63-65). A cross-sectional study that examined the role of dietary habits and their relation to obesity in 661 adolescents in Dubai, UAE, reported that children (boys and girls) who always consumed breakfast had a lower tendency to develop obesity (63). Factors leading to the risk of developing obesity included having breakfast at school rather than home, midnight snacking, watching television during meals and consuming so-called "fast-foods".

Several factors are associated with the recent rise in obesity in the Arab world. Some factors that are thought to play major roles include rapid urbanization, the consumption of high-fat fast-foods, an inactive lifestyle and a lack of outdoor activities due to the hot and dusty climate in this region.

The prevalence of obesity and diabetes is higher in females in the Arab population. Important in this context are cultural reasons related to multiple pregnancies at short intervals and the long-held view of overweight as a 


\begin{tabular}{|c|c|c|c|c|c|}
\hline Author (reference) & Country & Year & Sample size & Main findings & Notes \\
\hline Punnose (43) & UAE & 2005 & 96 & $\begin{array}{l}11 \text { children diagnosed with T2DM } \\
9 / 11 \text { children were Arab origin } \\
8 / 11 \text { children were overweight or obese } \\
\text { 10/11 children were female }\end{array}$ & $\begin{array}{l}\text { (8-18 years old) } \\
\text { Case series }\end{array}$ \\
\hline Moussa (117) & Kuwait & 2008 & 128918 & $\begin{array}{l}\text { T2DM found in } 45 \text { children } \\
\text { Prevalence of T2DM in male children: } \\
47.3 / 10000 \\
\text { Prevalence of T2DM in female children: } \\
26.3 / 10000(P=0.05)\end{array}$ & $\begin{array}{l}(6-18 \text { years old }) \\
\text { Medical record review } \\
\text { No recorded BMI }\end{array}$ \\
\hline Al-Agha (133) & $\begin{array}{l}\text { Saudi } \\
\text { Arabia }\end{array}$ & 2012 & 387 & $\begin{array}{l}\text { Prevalence of } \mathrm{T} 2 \mathrm{DM}: 9.04 \% \\
\text { Prevalence of } \mathrm{BMI} \geq 85 \text { th percentile in } \\
\text { diabetics: } 62.86 \% \\
\text { Prevalence of } \mathrm{BMI} \geq 95 \text { th percentile in } \\
\text { diabetics: } 37.14 \%\end{array}$ & $\begin{array}{l}(2-18 \text { years old }) \\
\text { Retrospective cross- } \\
\text { sectional study }\end{array}$ \\
\hline Ali (110) & Egypt & 2013 & & $\begin{array}{l}28 \text { out of } 210 \text { children with diabetes } \\
\text { diagnosed with T2DM } \\
64.3 \% \text { of T2DM children were female } \\
(\mathrm{P}=0.04) \\
71.4 \text { of T2DM children had positive } \\
\text { family history }(\mathrm{P}=0.01) \\
\text { Mean waist circumference in T2DM } \\
\text { patients: } 74.8 \mathrm{~cm} \\
\text { Mean waist circumference in type-1 } \\
\text { diabetes patients: } 64.4 \mathrm{~cm}(\mathrm{P}=0.002)\end{array}$ & $\begin{array}{l}\text { (1-18 years old) } \\
\text { Diagnosis of T2DM } \\
\text { based on fasting serum } \\
\text { C-peptide levels }\end{array}$ \\
\hline Osman (44) & Sudan & 2013 & 958 & $\begin{array}{l}\text { 38/985 children identified with T2DM } \\
32 / 38 \text { of cases were from tribes of Arab } \\
\text { origin } \\
\text { Prevalence of obesity among diabetic } \\
\text { children: } 76 \% \\
\text { Prevalence of overweight among } \\
\text { diabetic children: } 22 \%\end{array}$ & (11-18 years old) \\
\hline Musaiger (61) & $\begin{array}{l}\text { Arab } \\
\text { region }\end{array}$ & 2012 & 4698 & $\begin{array}{l}\text { Prevalence of obesity in males: } 4.1 \% \\
\text { (Algeria), 34.8\% (Kuwait) } \\
\text { Prevalence of obesity in females: } 4.5 \% \\
\text { (Algeria), 20.6\% (Kuwait) } \\
\text { Prevalence of overweight in males: } 9.3 \% \\
\text { (Algeria), } 25.6 \% \text { (Kuwait) } \\
\text { Prevalence of overweight in females: } \\
12.5 \% \text { (Palestine), 26.6\% (Kuwait) }\end{array}$ & (15-18 years old) \\
\hline Ehtisham (42) & UK & 2000 & 8 & $\begin{array}{l}\text { First } 8 \text { cases reported with T2DM in UK } \\
\text { All cases were overweight and } \\
\text { originated from India, Pakistan and Arab } \\
\text { countries }\end{array}$ & (9-16 years old) \\
\hline
\end{tabular}

$U A E=$ United Arab Emirates $; K=$ United Kingdom.

desirable physique reflecting economic well-being (4).

Another important factor to be considered is the association between educational level and the prevalence of obesity. The majority ( $82 \%$ ) of diabetic female Arab immigrants to the USA had limited education (high school level or below), while the percentage of women with less than high school education in a normal glucose tolerance group was $42 \%(66)$.

\section{Genetic implications}

Despite the multiple lifestyle-based factors linking obesity to diabetes in Arab countries, there is also evidence for a strong genetically-based association between obesity and diabetes in Arab populations (Table 5).

Adiponectin is a hormone released by adipocytes (see the section on Pathological mechanisms above) that is encoded by the $A D I P O Q$ gene (67).
Several studies have reported reduced adiponectin levels secondary to novel variations in the ADIPOQ gene (6872). There are 149 variants identified in the ADIPOQ gene (73). Although the number of variations are not directly associated with T2DM, these variations may affect insulin sensitivity in obese diabetic patients $(69,74)$. In addition, variations in the $A D I P O Q$ gene show a significant association with increased $\operatorname{BMI}(75,76)$. 


\begin{tabular}{|c|c|c|c|c|c|}
\hline Author (reference) & Country & Year & Sample size & Main findings & Notes \\
\hline Alkhateeb (78) & Jordan & 2013 & 650 & $\begin{array}{l}\text { Number of subjects carrying variants of } \\
\text { ADIPOQ gene was significantly higher in } \\
\text { diabetic group. } \\
\text { All subjects were Jordanians }\end{array}$ & $\begin{array}{l}\text { T2DM: } 420 \\
\text { Controls: } 230\end{array}$ \\
\hline Mtiraoui (73) & Tunisia & 2012 & 1665 & $\begin{array}{l}\text { Significantly higher number of the diabetic } \\
\text { patients carried } 6 \text { of } 13 \text { variants of ADIPOQ } \\
\text { gene. } \\
\text { All subjects were unrelated Tunisians }\end{array}$ & $\begin{array}{l}\text { T2DM: } 917 \\
\text { Controls: } 748\end{array}$ \\
\hline Zadjali (77) & Oman & 2013 & 328 & $\begin{array}{l}\text { rs266729 variant in ADIPOQ gene (identified } \\
\text { in Tunisian and Jordanian diabetics as well) } \\
\text { was associated with body weight }(P=0.001) \text {, } \\
\text { waist circumference }(P=0.037), B M I(P=0.015) \\
\text { and percentage of total body fat }(P=0.003) \text { in } \\
\text { Omani subjects }\end{array}$ & $\begin{array}{l}\text { All subjects from one } \\
\text { extended Omani } \\
\text { family }\end{array}$ \\
\hline Wakil (81) & $\begin{array}{l}\text { Saudi } \\
\text { Arabia }\end{array}$ & 2006 & 1173 & $\begin{array}{l}\text { Frequency of } \mathrm{P} \text { allele of PPAR- } \gamma \text { gene was } 0.974 \\
\text { and } 0.968 \text { in T2DM patients and controls } \\
\text { respectively }\end{array}$ & $\begin{array}{l}\text { Underpowered due } \\
\text { to high incidence in } \\
\text { both groups }\end{array}$ \\
\hline Nemr (89) & Lebanon & 2012 & 1422 & $\begin{array}{l}\text { Average of minor allelic frequency of } 2 \text { variants } \\
\text { of CDKAL1 gene was significantly higher in } \\
\text { Lebanese type- } 2 \text { diabetic patients }(P<0.001) \text {. } \\
\text { All subjects were unrelated Lebanese patients }\end{array}$ & $\begin{array}{l}\text { T2DM: } 630 \\
\text { Controls: } 792\end{array}$ \\
\hline Nemr (92) & Lebanon & 2012 & 1150 & $\begin{array}{l}\text { Two variants of IGF2BP2 gene (rs } 4402960 \text { and } \\
\text { rs } 1470579 \text { ) were significantly associated with } \\
\text { T2DM in Lebanese patients }\end{array}$ & $\begin{array}{l}\text { T2DM: } 544 \\
\text { Controls: } 606\end{array}$ \\
\hline Almawi (93) & Lebanon & 2013 & & $\begin{array}{l}\text { Five variants (rs792837 in COL8A1, rs2237892 } \\
\text { and rs2237895 in KCNQ1, rs729287 in ALX4 } \\
\text { and rs4430796 in HNF1) were associated with } \\
\text { T2DM }\end{array}$ & $\begin{array}{l}\text { T2DM: } 995 \\
\text { Controls: } 1076\end{array}$ \\
\hline
\end{tabular}

Although studies on ADIPOQ genetic variations in Arab populations are still limited and there are no metaanalyses showing the frequency of $\mathrm{Ar}-$ abs carrying variants of the $A D I P O Q$ gene, several researchers have reported that a statistically significant number of Arab obese diabetic patients carry variants of the $A D I P O Q$ gene $(73,77)$.

The association between variants of the ADIPOQ gene [the singlenucleotide polymorphism (SNP) of rs266729] and the prevalence of diabetes was studied in a Jordanian population that included 420 diabetic and 230 normoglycaemic patients (78). A greater number of diabetic patients carried variants in the $A D I P O Q$ gene, suggesting that mutations in the $A D I$ $P O Q$ gene strongly correlated with the risk of T2DM, at least in Jordanians. A related study of unrelated Tunisians investigated 13 different polymorphisms of the ADIPOQ gene in 917 diabetic and 748 non-diabetic control individuals. Among the 13 variants tested, a significantly higher number of diabetic patients carried 6 of the minor allelic of variants (73). Of interest is that one of the variants that showed a strong association with T2DM was the same variant (rs266729) found in the Jordanian study (73,78). A recent cross-sectional analysis examined the association of genetic variants of the ADIPOQ gene with obesity, insulin resistance, dyslipidaemia and hypertension in 328 people from one extended Omani family living in an area where first-cousin marriages represented $50 \%$ of all marriages (77). The prevalence of obesity and diabetes were $17 \%$ and $27 \%$ respectively. Two common variants of the ADIPOQ gene were identified. The frequency of SNP of rs266729 (the same SNP identified in Tunisian and Jordanian studies) significantly correlated with body weight $(P=0.001)$, waist circumference $(P=0.037)$, BMI $(P=$ $0.015)$ and percentage of total body fat $(P=0.003)$.

As diabetes is a complex of mechanisms ultimately leading to high blood sugar levels, several studies have attempted to identify variants in different genes that may be related to the increased risk of diabetes. For example, the nuclear receptor protein peroxisome proliferator-activated receptor gamma (PPAR- $\gamma$ ) is of central interest in the pathogenesis of diabetes, obesity and other metabolic disorders. Activation of PPAR- $\gamma$ by the thiazolidinedione type of oral hypoglycaemic drugs improves insulin sensitivity and thus control of diabetes (79). Mutations in the PPAR- $\gamma$ gene, specifically the Pro 12Ala polymorphism, could be a risk factor for diabetes $(80)$. The first study examining the $P$ allele (i.e. the risk allele) variant of the $P P A R-\gamma$ gene 
in Arabs took place in Saudi Arabia. A case-controlled study reported that the frequency of the $P$ allele was 0.974 and 0.968 in T2DM patients and control subjects respectively $(P=0.633)$ It is likely that the similarity in these values represented the high incidence of the risk allele in the population tested (81). In addition, the presence of the $P$ allele in the Saudi Arabian population in neonatal samples revealed a frequency of 0.957 , which is similar to the frequencies found in Japanese, Chinese and African-Americans and was among the highest $(81,82)$. Despite the high incidence of the risk allele in the Saudi population, there are other factors at play in the increased risk of diabetes among more recent generations of the population, among whom first-cousin marriages represent about $30 \%$ of all marriages and marriages to distant relatives has a frequency of $15 \%$. These findings increase the rate of consanguinity to nearly $60 \%$, and increase the odds of familial aggregation of T2DM to 6.2 $(83,84)$.

Genome-wide association studies (GWAS) identified several gene variants associated with T2DM. These included the CDKAL1 SNP, which is thought to be a major genetic risk factor for T2DM in several ethnic groups. Mutations in the CDKAL1 gene impair beta-cell function without affecting insulin sensitivity (85-87). Notably, variants of the CDKAL1 gene were shown to have no association with T2DM in Moroccan patients (88). However, in a Lebanese study there appeared to be an association between T2DM and 2 common variants of the CDKAL1 gene (89).

Variants in the insulin-like binding protein 2 (IGF2BP2) gene are associated with T2DM in several ethnic groups $(90,91)$. A replicate study in a Lebanese Arabs population identified 2 SNPs of IGF2BP2 (rs4402960 and rs 1470579) that were strongly associated with T2DM (92). Moreover, an additional cross-sectional replication study in Arab-Lebanese was able to genotype 19 representative SNPs in 15 potential T2DM loci, derived earlier from the European GWAS (93). After correcting for multiple comparisons, their findings revealed that 5 SNPs (rs792837 in the COL8Al gene, rs2237892 and rs2237895 in KCNQ1, rs729287 in ALX4 and rs4430796 in HNF1) were significantly associated with T2DM.

Finally, the search for genetic determinants of diabetes and obesity within Arab populations has recently become a focus of attention. However, comprehensive coverage of this topic is beyond the scope of this review.

\section{Ongoing efforts to combat obesity- linked diabetes}

The prevalence of obesity in Arab populations is a major concern. In addition to the risk of developing diabetes, obesity increases the risk of hypertension, cardiovascular diseases and some types of cancers. In fact, these complications represent about $50 \%$ of all deaths in the Arab region (94).

Obesity-linked diabetes is a preventable disease, and decreasing body weight reduces the risk of T2DM and its complications (95-97). Such findings encouraged decision-makers in different Arab nations to collaborate in trying to limit the rise in obesity-related diabetes.

The Arab Taskforce for Obesity and Physical Activity developed a 5-year strategy to combat obesity (98), and first presented this at the Third Arab Conference on Obesity held in Bahrain in 2010 where there were contributions from 14 Arab countries. The proposed strategy aimed to suit all Arab nations in a manner that was consistent with the diversity of socioeconomic status and cultures across the region. The primary goals of the strategy are to:
- promote healthy dietary habits and increase physical activities to reduce the incidence of overweight and obesity;

- reduce risk factors for noncommunicable diseases resulting from obesity, poor dietary habits and lack of physical activity;

- raise awareness about the complications of obesity and the overall benefits of increasing physical activity in preventing complications;

- enhance collaborations between governments, the private sector and community institutions to provide healthy environments through healthy lifestyles;

- conduct research related to nutrition and the risk factors for obesity; and

- develop national guidelines for controlling the rise in obesity, particularly in children (98-100).

\section{Future directions}

Although the prevalence of obesityrelated T2DM is increasing rapidly in all age groups of the population in the Arab world, the extent of investigation into this phenomenon and the measures aimed at curbing the epidemic are insufficient. Crucial information on obesity and diabetes in various Arab populations is not available. Studies concerning the ethnic-specific obesity cut-off points for the risk of diabetes exist for other ethnic groups. For example, it has been shown that BMI values of 25 $\mathrm{kg} / \mathrm{m}^{2}$ (South Asian) and $27 \mathrm{~kg} / \mathrm{m}^{2}$ (African-Caribbean) carry a risk of developing T2DM equivalent to a BMI of $30 \mathrm{~kg} / \mathrm{m}^{2}$ for Europeans (101). Another prospective cohort study investigated the protective effect of physical activity, using 65 identified SNPs as genetic risk markers for T2DM in a population of White participants who were tracked for a mean of 7.8 years (102). Predictably, the incidence of T2DM was lower in physically active subjects, but the 
strongest association between physical activity and the incidence of T2DM was observed in a group with a low genetic risk score and, conversely, the weakest association occurred in the high genetic risk group. These results suggest that the protective effect of physical activity against T2DM is highly dependent on the genetic risk an individual is carrying, and these data may be of importance in Arab populations that have traditions of consanguineous marriages.

The lack of sufficient GWAS in T2DM is troublesome, particularly in the context of the epidemic of obesity and diabetes in Arab populations. A recent systematic overview of genetic studies of T2DM in South Asians reported that the only 2 GWAS performed in South Asian diabetics were able to identify susceptibility genes that were not detected in European GWAS (103). Other studies in Caucasian Europeans reported significant variations in serum adiponectin levels after 4 weeks of high monounsaturated fatty acids diets; variations were attributed to genetic polymorphisms at the ADI$P O Q$ gene locus (104). On the other hand, a study of Saudi Arabians with T2DM found no significant association between 2 SNPs (T45G and G276T) and circulating adiponectin or insulin resistance (105).

The very limited GWAS performed in diabetic and obese Arab populations have yielded valuable information, indicating that more studies might add crucial insight into T2DM in terms of prevention or even treatment. Therefore, the search for genetic determinants of diabetes and obesity in Arab populations should be prioritized.

\section{Summary}

Diabetes has a complex pathophysiology and management strategy. Obesity is the main risk factor attributed to diabetes in the Arab world. The sedentary lifestyle in most of Arab countries, coupled with a hot climate and unique cultural barriers to physical activities, are important factors to be considered in the rapid increase in the prevalence of obesity among Arab countries. However, studies among Arab migrants to countries where the lifestyle is known to be more active, showed that the risks of obesity and diabetes remain elevated. For example, the Australian Institute of Health and Welfare reports that immigrants from the Middle East and North Africa have the highest prevalence of diabetes and the second highest prevalences of overweight, hospitalization and mortality related to diabetes among all immigrants to Australia (60).

Most of the available epidemiological data show that Arab females are more prone to obesity and diabetes. Several factors could account for these findings, but especially important are the persistent social and cultural barriers to physical activities. Recently published data on T2DM in children and adolescents are concerning. This unusual age-related disease has been highlighted in several epidemiological studies of the prevalence of obesity in Arab schoolchildren.

The widespread epidemic of obesity-related diabetes in Arab populations has been analysed in a limited number of genetic studies. For example, the variant rs266729 in the ADIPOQ gene was significantly associated with diabetes in Tunisian and Jordanian populations, and with obesity in an extended Omani family. Another factor aggravating the genetic basis for T2DM in Arab countries is the common practice of marriage with first- or second-degree relatives. In a study of Saudi Arabian males nearly $63 \%$ of diabetics had a positive family history of diabetes compared with around $22 \%$ in the control non-diabetic group $(P<0.0001)$. These data suggest that familial aggregation increases the risk of diabetes with an odds ratio of 6.2 (106). The study also found that marrying relatives was strongly correlated with diabetes; nearly $80 \%$ of people in consanguineous marriages had a family history of diabetes versus around $21 \%$ in a non-consanguineous marriage group $(P<0.0001)$, giving an odds ratio of $14: 3$.

Strategies for combatting obesity in the Arab world by the Arab Taskforce for Obesity and Physical Activity appear promising, although this requires sustained collaboration among many decision-makers across the region.

Finally, there is a lack of quality data regarding obesity-related diabetes in Arab populations. Gaps exist in our information about diabetes and obesity, in particular in relation to ethnicspecific cut-off points for diagnosis and treatment of diabetes. In addition, further GWAS in obese and diabetic Arab populations could add to our understanding of the pathophysiology, prevention and reversal of this disease.

\section{Limitations}

There were both limitations and strengths of this literature review. First, we critically appraised only those studies that met our inclusion criteria. Secondly, despite sociocultural similarities among Arab countries, ethnic differences between populations may well play a significant role in the epidemiological variations related to obesity and diabetes, since the Arab population is widely distributed across both Asia and Africa. Nevertheless, we aimed to comprehensively review the burden of obesity-related T2DM in the Arab world by carefully evaluating the available epidemiological data from each country. To our knowledge, this is the first paper to explore the great health burden of T2DM in children and adolescents in the Arab world.

\section{Acknowledgements}

Funding: None.

Competing interests: None declared. 


\section{References}

1. IDF diabetes atlas. 4th ed. Brussels: International Diabetes Federation; 2008 (http://www.idf.org/sites/default/files/ IDF-Diabetes-Atlas-4th-edition.pdf, accessed 10 June 2015).

2. American Diabetes Association. Economic costs of diabetes in the U.S. in 2007. Diabetes Care. 2008 Mar;31(3):596-615. PMID:18308683

3. World health statistics 2008. Geneva: World Health Organization; 2008 (http://www.who.int/whosis/whostat/2008/en/, accessed 10 June 2015).

4. Assaad-Khalil SH, Al Arouj M, Almaatouq M, Amod A, Assaad $\mathrm{SN}$, Azar ST, et al. Barriers to the delivery of diabetes care in the Middle East and South Africa: a survey of 1,082 practising physicians in five countries. Int J Clin Pract. 2013 Nov;67(11):114450. PMID:24165428.

5. Al-Maskari F, El-Sadig M, Nagelkerke N. Assessment of the direct medical costs of diabetes mellitus and its complications in the United Arab Emirates. BMC Public Health. 2010;10:679. PMID:21059202

6. Bonora E, Targher G, Formentini G, Calcaterra F, Lombardi S, Marini F, et al. The metabolic syndrome is an independent predictor of cardiovascular disease in Type 2 diabetic subjects. Prospective data from the Verona Diabetes Complications Study. Diabet Med. 2004 Jan;21(1):52-8. PMID:14706054

7. Masuo K, Rakugi H, Ogihara T, Esler MD, Lambert GW. CardioK vascular and renal complications of type 2 diabetes in obesity: role of sympathetic nerve activity and insulin resistance. Curr Diabetes Rev. 2010 Mar;6(2):58-67. PMID:20034369

8. Raz I. Complex impact of obesity on type 2 diabetes. Isr Med Assoc J. 2005;7:402-3.

9. Montague $\mathrm{CT}$, O'Rahilly S. The perils of portliness: causes and consequences of visceral adiposity. Diabetes. 2000 Jun;49(6):883-8. PMID:10866038

10. Must A, Spadano J, Coakley EH, Field AE, Colditz G, Dietz WH. The disease burden associated with overweight and obesity. JAMA. 1999 Oct 27;282(16):1523-9. PMID:10546691

11. Mokdad AH, Ford ES, Bowman BA, Dietz WH, Vinicor F, Bales VS, et al. Prevalence of obesity, diabetes, and obesityrelated health risk factors, 2001. JAMA. 2003 Jan 1;289(1):76-9. PMID:12503980

12. Khan S. Mechanisms linking obesity to insulin resistance and type 2 diabetes. Nature. 2006 Dec 14;444(7121):840-6. PMID:17167471

13. Day C, Bailey C. Obesity in the pathogenesis of type 2 diabetes. Br J Diabetes Vasc Dis. 2011;11:55-61.

14. Karpe F, Dickmann JR, Frayn KN. Fatty acids, obesity, and insulin resistance: time for a reevaluation. Diabetes. 2011;60(10):2441-9. PMID:21948998

15. Santomauro AT, Boden G, Silva ME, Rocha DM, Santos RF, Ursich MJ, Strassmann PG, Wajchenberg BL. Overnight lowering of free fatty acids with Acipimox improves insulin resistance and glucose tolerance in obese diabetic and nondiabetic subjects. Diabetes. 1999 Sep;48(9):1836-41. PMID:10480616

16. Thévenod F. Masur K, Thévenod F, Zänker KS, eds. Diabetes and cancer. Epidemiological evidence and molecular links. Front diabetes. Volume 19. Basel: Karger; 2008 pp 1-18 (https://www.karger.com/ProdukteDB/Katalogteile/ isbn3_8055/_86/_40/fdiab19_02.pdf, accessed 10 June 2015).

17. Havel PJ. Update on adipocyte hormones: regulation of energy balance and carbohydratelipid metabolism. Diabetes. 2004 Feb;53 Suppl 1:S143-51.PMID:14749280
18. Hajer GR, van Haeften TW, Visseren FL. Adipose tissue dysfunction in obesity, diabetes, and vascular diseases. Eur Heart J. 2008 Dec;29(24):2959-71. PMID:18775919

19. Kusminski CM, McTernan PG, Kumar S. Role of resistin in obesity, insulin resistance and Type II diabetes. Clin Sci (Lond). 2005 Sep;109(3):243-56. PMID:16104844

20. Scherer PE, Williams S, Fogliano M, Baldini G, Lodish HF. A novel serum protein similar to $\mathrm{Clq}$, produced exclusively in adipocytes. J Biol Chem. 1995 Nov 10;270(45):26746-9. PMID:7592907

21. Ryu S, Park S, Kim S. The relation of serum adiponectin and resistin concentrations with metabolic risk factors. J Korean Soc Endocrinol. 2005;20(5):444-51.

22. Yamamoto $Y$, Hirose $H$, Saito I, Tomita M, Taniyama M, Matsubara K, et al. Correlation of the adipocyte-derived protein adiponectin with insulin resistance index and serum high-density lipoprotein-cholesterol, independent of body mass index, in the Japanese population. Clin Sci (Lond). 2002 Aug;103(2):137-42. PMID:12149104

23. Kern PA, Di Gregorio GB, Lu T, Rassouli N, Ranganathan G. Adiponectin expression from human adipose tissue: relation to obesity, insulin resistance, and tumor necrosis factoralpha expression. Diabetes. 2003 Jul;52(7):1779-85. Diabetes. PMID:12829646

24. Lihn AS, Pedersen SB, Richelsen B. Adiponectin: action, regulation and association to insulin sensitivity. Obes Rev. 2005 Feb;6(1):13-21. PMID:15655035

25. Alfadda AA. Circulating adipokines in healthy versus unhealthy overweight and obese subjects. Int J Endocrinol. 2014;2014:170434. PMID:24550983

26. Abdullah AR, Hasan HA, Raigangar VL. Analysis of the relationship of leptin, high-sensitivity C-reactive protein, adiponectin, insulin, and uric acid to metabolic syndrome in lean, overweight, and obese young females. Metab Syndr Relat Disord. 2009 Feb;7(1):17-22. PMID:19025443

27. Rizk N, Awni R, Osman M. M Zirie. Hypoadiponectinemia in obese and diabetic subjects in the State of Qatar. Int J Diabetes Metab. 2008;16:123-9.

28. Abaza D, El Arab A, Mohamed E, El Arab H. The relation between asthma, body fat distribution and serum adiponectin in obese Egyptian children. Egypt J Hosp Med. 2011;45:585-94.

29. Morris DL, Rui L. Recent advances in understanding leptin signaling and leptin resistance. Am J Physiol Endocrinol Metab. 2009 Dec;297(6):E1247-59. PMID:19724019

30. Yang R, Barouch LA. Leptin signaling and obesity: cardiovascular consequences. Circ Res. 2007 Sep 14;101(6):545-59. PMID:17872473

31. Silha JV, Krsek M, Skrha JV, Sucharda P, Nyomba BL, Murphy LJ. Plasma resistin, adiponectin and leptin levels in lean and obese subjects: correlations with insulin resistance. Eur J Endocrinol. 2003 Oct;149(4):331-5. PMID:14514348

32. Adams-Huet B, Devaraj S, Siegel D, Jialal I. Increased adipose tissue insulin resistance in metabolic syndrome: relationship to circulating adipokines. Metab Syndr Relat Disord. 2014 Dec;12(10):503-7. PMID:25162912

33. Finucane FM, Luan J, Wareham NJ, Sharp SJ, O'Rahilly S, Balkau $\mathrm{B}$, et al. Correlation of the leptin:adiponectin ratio with measures of insulin resistance in non-diabetic individuals. Diabetologia. 2009 Nov; 52(11):2345-9.

34. Steppan CM, Bailey ST, Bhat S, Brown EJ, Banerjee RR, Wright $\mathrm{CM}$, et al. The hormone resistin links obesity to diabetes. Nature. 2001 Jan 18;409(6818):307-12. PMID:11201732 
35. Ukkola O. Resistin-a mediator of obesity-associated insulin resistance or an innocent bystander? Eur J Endocrinol. 2002 Nov;147(5):571-4. PMID:12444887

36. Gharibeh MY, Al Tawallbeh GM, Abboud MM, Radaideh A Alhader AA, Khabour OF. Correlation of plasma resistin with obesity and insulin resistance in type 2 diabetic patients. Diabetes Metab. 2010 Dec;36(6 Pt 1):443-9. PMID:20739208

37. Degawa-Yamauchi M, Bovenkerk JE, Juliar BE, Watson W, Kerr K, Jones R, et al. Serum resistin (FIZZ3) protein is increased in obese humans. J Clin Endocrinol Metab. 2003 Nov;88(11):5452-5. PMID:14602788

38. Lee JH, Chan JL, Yiannakouris N, Kontogianni M, Estrada E, Seip $R$, et al. Circulating resistin levels are not associated with obesitv ty or insulin resistance in humans and are not regulated by fasting or leptin administration: cross-sectional and interventional studies in normal, insulin-resistant, and diabetic subjects. J Clin Endocrinol Metab. 2003 Oct;88(10):4848-56. PMID:14557464

39. Iqbal N, Seshadri P, Stern L, Loh J, Kundu S, Jafar T, et al. Serum resistin is not associated with obesity or insulin resistance in humans. Eur Rev Med Pharmacol Sci. 2005 May-Jun;9(3):161-5. PMID:16080635

40. Chang YH, Chang DM, Lin KC, Shin SJ, Lee YJ. Visfatin in overweightobesity, type 2 diabetes mellitus, insulin resistance, metabolic syndrome and cardiovascular diseases: a metaanalysis and systemic review. Diabetes Metab Res Rev. 2011 Sep;27(6):515-27. PMID:21484978

41. Izadi M, Goodarzi M, Khalaj H, Khorshidi D, Doali H. Serum adiponectin levels are inversely correlated with insulin resistance in obese men with type 2 diabetes. Int J Endocrinol Metab. 2011;9(1):253-7.

42. Ehtisham S, Barrett TG, Shaw NJ. Type 2 diabetes mellitus in UK children-an emerging problem. Diabet Med. 2000 Dec;17(12):867-71. PMID:11168330

43. Punnose J, Agarwal MM, Bin-Uthman S. Type 2 diabetes mel litus among children and adolescents in Al-Ain: a case series. East Mediterr Health J. 2005 Jul;11(4):788-97. PMID:16700395

44. Osman H, Elsadek N, Abdullah M. Type 2 diabetes in Sudanese children and adolescents. Sudan J Paediatr. 2013;13(2):17-23.

45. Ng M, Fleming T, Robinson M, Thomson B, Graetz N, Margono $\mathrm{C}$, et al. Global, regional, and national prevalence of ovee rweight and obesity in children and adults during 1980-2013: a systematic analysis for the Global Burden of Disease Study 2013. Lancet. 2014;30;384(9945):766-81. PMID:24880830

46. Hossain P, Kawar B, El Nahas M. Obesity and diabetes in the developing world-a growing challenge. N Engl J Med. 2007 Jan 18;356(3):213-5. PMID:17229948

47. Boutayeb A, Lamlili MEN, Boutayeb W, Maamri A, Ziyyat A Ramdani N. The rise of diabetes prevalence in the Arab region. Open Journal of Epidemiology. 2012;2:55-60. doi: 10.4236/ ojepi.2012.22009

48. Al-Nozha MM, Al-Mazrou YY, Al-Maatouq MA, Arafah MR, Khalil MZ, Khan NB, et al. Obesity in Saudi Arabia. Saudi Med J. 2005 May;26(5):824-9. PMID:15951877

49. el-Hazmi MA, Warsy AS. Prevalence of overweight and obesity in diabetic and non-diabetic Saudis. East Mediterr Health J. 2000 Mar-May;6(2-3):276-82. PMID:11556013

50. Al-Shahrani A, Al-Khaldi Y. Obesity among diabetic and hypertensive patients in Aseer region, Saudi Arabia. Saudi J Obes. 2013;1(1):14-7.

51. IDF diabetes atlas, 6th ed. Brussels: International Diabetes Federation; 2013 http:// www.idf.orgdiabetesatlas, accessed 10 June 2015).

52. Alarouj M, Bennakhi A, Alnesef Y, Sharifi M, Elkum N. Diabetes and associated cardiovascular risk factors in the State of $\mathrm{Ku}$ - wait: the first national survey. Int J Clin Pract. 2013 Jan;67(1):8996. PMID:23241053

53. Malik M, Bakir A, Saab BA, King H. Glucose intolerance and associated factors in the multi-ethnic population of the United Arab Emirates: results of a national survey. Diabetes Res Clin Pract. 2005 Aug;69(2):188-95. PMID:16005369

54. Arafat M, Salam A, Arafat O. The association of type 2 diabetes with obesity and other factors: in multinational community. Int J Pharm Pharm Sci. 2014;6(9):257-60.

55. Alhyas L, McKay A, Balasanthiran A, Majeed A. Prevalences of overweight, obesity, hyperglycaemia, hypertension and dyslipidaemia in the Gulf: systematic review. JRSM Short Rep. 2011 Jul; 2(7):55.

56. Bos M, Agyemang C. Prevalence and complications of diabetes mellitus in Northern Africa, a systematic review. BMC Public Health. 2013;13:387. PMID:23617762

57. Jaber LA, Brown MB, Hammad A, Nowak SN, Zhu Q, Ghafoor A, et al. Epidemiology of diabetes among Arab Americans. Diabetes Care. 2003 Feb;26(2):308-13. PMID:12547854

58. Musaiger A, Shahbeek N. The relationship between obesity and prevalence of chronic diseases in the Arab women. J Hum Ecol. Special Issue. 2005;13:97-100.

59. Rissel C, Lesjak M, Ward J. Cardiovascular risk factors among Arabic-speaking patients attending Arabic-speaking general practitioners in Sydney, Australia: opportunities for intervention. Ethn Health. 1998 Aug;3(3):213-22. PMID:9798119

60. Thow AM, Waters AM. AIHW 2005. Diabetes in culturally and linguistically diverse Australians. Cat. no. CVD 30. Canberra: Australian Institute of Health and Welfare; 2005.

61. Musaiger AO, Al-Mannai M, Tayyem R, Al-Lalla O, Ali EY, Kalam $\mathrm{F}$, et al. Prevalence of overweight and obesity among adolescents in seven arab countries: a cross-cultural study. J Obes. 2012;2012:981390. PMID:23029605

62. Musaiger AO, Al-Mannai M, Al-Lalla O, Saghir S, Halahleh I, Benhamed MM, et al. Obesity among adolescents in five Arab countries; relative to gender and age. Nutr Hosp. 2013 NovDec;28(6):1922-5. PMID:24506370

63. bin Zaal AA, Musaiger AO, D'Souza R; BinZaal AA. Dietary habits associated with obesity among adolescents in Dubai, United Arab Emirates. Nutr Hosp. 2009 Jul-Aug;24(4):437-44. PMID:19721923

64. Musaiger AO. Overweight and obesity in Eastern Mediterranean Region: prevalence and possible causes. J Obes. 2011;2011:407237. doi: 10.11552011407237.

65. Musaiger AO, Lloyd OL, Al-Neyadi SM, Bener AB. Lifestyle factors associated with obesity among male university students in the United Arab Emirates. J Nutr Food Sci. 2003;33(4):145-7.

66. Jaber LA, Brown MB, Hammad A, Zhu Q, Herman WH. Lack of acculturation is a risk factor for diabetes in Arab immigrants in the US. Diabetes Care. 2003 Jul;26(7):2010-4. PMID:12832304

67. Mackevics V, Heid IM, Wagner SA, Cip P, Doppelmayr H Lejnieks A, et al. The adiponectin gene is associated with adiponectin levels but not with characteristics of the insulin resistance syndrome in healthy Caucasians. Eur J Hum Genet. 2006 Mar;14(3):349-56. PMID:16418740

68. Jungtrakoon $\mathrm{P}$, Plengvidhya $\mathrm{N}$, Tangjittipokin $\mathrm{W}$, Chimnaronk S, Salaemae W, Chongjaroen N, et al. Novel adiponectin variants identified in type 2 diabetic patients reveal multimerization and secretion defects. PLoS One. 2011;6(10):e26792. PMID:22046359

69. Siitonen N, Pulkkinen L, Lindström J, Kolehmainen M, Eriksson JG, Venojärvi M, et al. Association of ADIPOQ gene variants with body weight, type 2 diabetes and serum adiponectin concentrations: the Finnish Diabetes Prevention Study. BMC Med Genet. 2011;12:5. PMID:21219602 
70. Kottyan L, Woo JG, Keddache M, Banach W, Crimmins NA, Dolan LM, et al. Novel variations in the adiponectin gene (ADIPOQ) may affect distribution of oligomeric complexes. Springerplus. 2012 Dec;1(1):66. PMID:23396303

71. Ramya K, Ayyappa KA, Ghosh S, Mohan V, Radha V. Genetic association of ADIPOQ gene variants with type 2 diabetes, obesity and serum adiponectin levels in south Indian population. Gene. 2013 Dec 15;532(2):253-62. PMID:24055485

72. Martin LJ, Woo JG, Daniels SR, Goodman E, Dolan LM. The relationships of adiponectin with insulin and lipids are strengthened with increasing adiposity. J Clin Endocrinol Metab. 2005 Jul;90(7):4255-9. PMID:15870125

73. Mtiraoui N, Ezzidi I, Turki A, Chaieb A, Mahjoub T, Almawi WY. Single-nucleotide polymorphisms and haplotypes in the adiponectin gene contribute to the genetic risk for type 2 diabetes in Tunisian Arabs. Diabetes Res Clin Pract. 2012 Aug;97(2):290-7. PMID:22497971

74. Chiodini BD, Specchia C, Gori F, Barlera S, D'Orazio A, Pietri S et al.; GISSI Prevenzione Investigators; SiBioC-GISSI Prevenzione Group. Adiponectin gene polymorphisms and their effect on the risk of myocardial infarction and type 2 diabetes: an association study in an Italian population. Ther Adv Cardiovasc Dis. 2010 Aug;4(4):223-30. PMID:20576642

75. Beebe-Dimmer JL, Zuhlke KA, Ray AM, Lange EM, Cooney KA. Genetic variation in adiponectin (ADIPOQ) and the type 1 receptor (ADIPOR1), obesity and prostate cancer in African Americans. Prostate Cancer Prostatic Dis. 2010 Dec;13(4):3628. PMID:20697428

76. Enns JE, Taylor CG, Zahradka P. Variations in adipokine genes AdipoQ, Lep, and LepR are associated with risk for obesity-related metabolic disease: the modulatory role of gene-nutrient interactions. J Obes. 2011;2011:168659. PMID:21773001

77. Zadjali F, Al-Yahyaee S, Hassan MO, Albarwani S, Bayoumi RA Association of adiponectin promoter variants with traits and clusters of metabolic syndrome in Arabs: family-based study. Gene. 2013 Sep 25;527(2):663-9. PMID:23845780

78. Alkhateeb A, Al-Azzam S, Zyadine R, Abuarqoub D. Genetic association of adiponectin with type 2 diabetes in Jordanian Arab population. Gene. 2013;512(1):61-3. PMID:23041553

79. Soriguer F, Morcillo S, Cardona F, Rojo-Martínez G, de la Cruz Almaráz M, Ruiz de Adana Mdel, et al. Pro12Ala polymord phism of the PPARG2 gene is associated with type 2 diabetes mellitus and peripheral insulin sensitivity in a population with a high intake of oleic acid. J Nutr. 2006 Sep;136(9):2325-30. PMID:16920849

80. Tönjes A, Stumvoll M. The role of the Pro12Ala polymorphism in peroxisome proliferator-activated receptor gamma in diabetes risk. Curr Opin Clin Nutr Metab Care. 2007 Jul;10(4):4104. PMID:17563457

81. Wakil SM, Al-Rubeaan K, Alsmadi O, Imtiaz F, Carroll P, Rajab $M$, et al. The peroxisome proliferator-activated receptor-gamma2 P12A polymorphism and type 2 diabetes in an Arab population. Diabetes Care. 2006 Jan;29(1):171-2. PMID:16373923

82. Meyer BF, Alsmadi O, Wakil S, Al-Rubeaan K. Genetics of type 2 diabetes in Arabs: what we know to date. Int J Diabetes Mellit. 2009;1(1):32-4.

83. el-Hazmi MA, al-Swailem AR, Warsy AS, al-Swailem AM, Sulaimani R, al-Meshari AA. Consanguinity among the Saudi Arabian population. J Med Genet. 1995 Aug;32(8):623-6. PMID:7473654

84. Cauchi S, Froguel P. Identification of genetic factors associated with Type 2 Diabetes in Saudis: The lessons from European studies. Int J Diabetes Mellit. 2010;2:133-6.

85. Steinthorsdottir V, Thorleifsson G, Reynisdottir I, Benediktsson $\mathrm{R}$, Jonsdottir T, Walters GB, et al. A variant in CDKAL1 influ- ences insulin response and risk of type 2 diabetes. Nat Genet. 2007 Jun;39(6):770-5. PMID:17460697

86. Pascoe L, Tura A, Patel SK, Ibrahim IM, Ferrannini E, Zeggini E, et al.; RISC Consortium; U.K. Type 2 Diabetes Genetics Consortium. Common variants of the novel type 2 diabetes genes CDKAL1 and HHEX/IDE are associated with decreased pancreatic beta-cell function. Diabetes. 2007 Dec;56(12):3101-4. PMID:17804762

87. Hertel JK, Johansson S, Raeder H, Midthjell K, Lyssenko V, Groop L, et al. Genetic analysis of recently identified type 2 diabetes loci in 1,638 unselected patients with type 2 diabetes and 1,858 control participants from a Norwegian population-based cohort (the HUNT study). Diabetologia. 2008 Jun;51(6):971-7. PMID:18437351

88. Cauchi S, Meyre D, Durand E, Proença C, Marre M, Hadjadj $S$, et al. Post genome-wide association studies of novel genes associated with type 2 diabetes show gene-gene interaction and high predictive value. PLoS One. 2008;3(5):e2031. PMID:18461161

89. Nemr R, Almawi AW, Echtay A, Sater MS, Daher HS, Almawi WY. Replication study of common variants in CDKAL1 and $\mathrm{CDKN} 2 \mathrm{~A} / 2 \mathrm{~B}$ genes associated with type 2 diabetes in Lebanese Arab population. Diabetes Res Clin Pract. 2012 Feb;95(2):e37-40. PMID:22119613

90. Ng MC, Park KS, Oh B, Tam CH, Cho YM, Shin HD, et al. Implication of genetic variants near TCF7L2, SLC30A8, HHEX, CDKAL1, CDKN2A/B, IGF2BP2, and FTO in type 2 diabetes and obesity in 6,719 Asians. Diabetes. 2008 Aug;57(8):2226-33. PMID:18469204

91. Grarup N, Rose CS, Andersson EA, Andersen G, Nielsen AL, Albrechtsen $A$, et al. Studies of association of variants near the HHEX, CDKN2A/B, and IGF2BP2 genes with type 2 diabetes and impaired insulin release in 10,705 Danish subjects: validation and extension of genome-wide association studies. Diabetes. 2007 Dec;56(12):3105-11. PMID:17827400

92. Nemr R, Echtay A, Dashti EA, Almawi AW, Al-Busaidi AS, Keleshian $\mathrm{SH}$, et al. Strong association of common variants in the IGF2BP2 gene with type 2 diabetes in Lebanese Arabs.Diabetes Res Clin Pract. 2012 May;96(2):225-9. PMID:22245690

93. Almawi WY, Nemr R, Keleshian SH, Echtay A, Saldanha FL, AlDoseri FA, et al. A replication study of 19 GWAS-validated type 2 diabetes at-risk variants in the Lebanese population. Diabetes Res Clin Pract. 2013 Nov;102(2):117-22. PMID:24145053

94. Non-communicable diseases [Internet]. Cairo: World Health Organization Regional Office for the Eastern Mediterranean (http://www.emro.who.int/entity/noncommunicable-diseases/index.html, accessed 11 June 2015).

95. Wing RR, Lang W, Wadden TA, Safford M, Knowler WC, Bertoni AG, et al.; Look AHEAD Research Group. Benefits of modest weight loss in improving cardiovascular risk factors in overweight and obese individuals with type 2 diabetes. Diabetes Care. 2011 Jul;34(7):1481-6. PMID:21593294

96. Bosello O, Armellini F, Zamboni M, Fitchet M. The benefits of modest weight loss in type II diabetes. Int J Obes Relat Metab Disord. 1997 Mar;21 Suppl 1:S10-3. PMID:9130035

97. Lau DC, Teoh H. Benefits of modest weight loss on the management of type 2 diabetes mellitus. Can J Diabetes. 2013 Apr;37(2):128-34. PMID:24070804

98. Musaiger AO, Al Hazzaa HM, Al-Qahtani A, Elati J, Ramadan J, Aboulella NA, et al. Strategy to combat obesity and to promote physical activity in Arab countries. Diabetes Metab Syndr Obes. 2011;4:89-97. PMID:21660292

99. The work of WHO in the Eastern Mediterranean Region: annual report of the Regional Director. Alexandria: World Health Organization Regional Office for the Eastern Mediterranean; 2003. 
100. Al-Shehri F, Moqbel M, Al-Shahrani A, Al-Khaldi Y, Abu-Melha W. Management of obesity: Saudi clinical guideline. Saudi. J Obes. 2013;1(1):18-30.

101. Tillin T, Sattar N, Godsland IF, Hughes AD, Chaturvedi N, Forouhi NG. -Ethnicity-specific obesity cut-points in the development of type 2 diabetes-a prospective study including three ethnic groups in the United Kingdom. Diabet Med. 2015 Feb;32(2):226-34. PMID:25186015

102. Klimentidis YC, Chen Z, Arora A, Hsu CH. Association of physical activity with lower type 2 diabetes incidence is weaker among individuals at high genetic risk. Diabetologia. 2014 Dec;57(12):2530-4. PMID:25273344

103. Chowdhury R, Narayan KM, Zabetian A, Raj S, Tabassum R. Genetic studies of type 2 diabetes in South Asians: a systematic overview. Curr Diabetes Rev. 2014;10(4):258-74. PMID:25001234

104. AlSaleh A, O'Dell SD, Frost GS, Griffin BA, Lovegrove JA, Jebb $\mathrm{SA}$, et al.; RISCK Study Group. Single nucleotide polymorphisms at the ADIPOQ gene locus interact with age and dietary intake of fat to determine serum adiponectin in subjects at risk of the metabolic syndrome. Am J Clin Nutr. 2011 Jul;94(1):2629. PMID:21562092

105. Al-Daghri NM, Al-Attas OS, Alokail MS, Alkharfy KM, Hussain $\mathrm{T}$, Yakout $\mathrm{S}$, et al. Adiponectin gene polymorphisms (T45C and G276T), adiponectin levels and risk for metabolic diseases in an Arab population. Gene. 2012 Feb 1;493(1):142-7. PMID:22155316

106. Anokute CC. Suspected synergism between consanguinity and familial aggregation in type 2 diabetes mellitus in Saudi Arabia. J R Soc Health. 1992 Aug;112(4):167-9. PMID:1433147

107. Farouq I. Al Zurba and Ahmad Al Garf - Prevalence of diabetes mellitus among Bahrainis attending primary health care centres. East Mediterr Health J. 1996;2(2):274-82.

108. Abolfotouh MA, Soliman LA, Mansour E, Farghaly M, ElDawaiaty AA. Central obesity among adults in Egypt: prevalence and associated morbidity. East Mediterr Health J. 2008 Jan-Feb;14(1):57-68. PMID:18557452

109. Herman WH, Ali MA, Aubert RE, Engelgau MM, Kenny SJ, Gunter EW, et al. Diabetes mellitus in Egypt: risk factors and prevalence. Diabet Med. 1995 Dec;12(12):1126-31. PMID:8750225

110. Ali BA, Abdallah ST, Abdallah AM, Hussein MM. The Frequency of Type 2 Diabetes Mellitus among Diabetic Children in EI Minia Governorate, Egypt. Sultan Qaboos Univ Med J. 2013 Aug;13(3):399-403. PMID:23984025

111. Saadi H, Carruthers SG, Nagelkerke N, Al-Maskari F, Afandi B, Reed R, et al. Prevalence of diabetes mellitus and its complications in a population-based sample in Al Ain, United Arab Emirates. Diabetes Res Clin Pract. 2007 Dec;78(3):369-77. PMID:17532085

112. Mansour AA, Al-Maliky AA, Kasem B, Jabar A, Mosbeh KA Prevalence of diagnosed and undiagnosed diabetes mellitus in adults aged 19 years and older in Basrah, Iraq. Diabetes Metab Syndr Obes. 2014;7:139-44. PMID:24833912

113. Mansour AA, Al-Jazairi MI. Predictors of incident diabetes mellitus in Basrah, Iraq. Ann Nutr Metab. 2007;51(3):277-80. PMID:17622787

114. Ajlouni K, Khader YS, Batieha A, Ajlouni H, El-Khateeb M. An increase in prevalence of diabetes mellitus in Jordan over 10 years. J Diabetes Complications. 2008 Sep-Oct;22(5):317-24. PMID:18413210

115. Al Khalaf MM, Eid MM, Najjar HA, Alhajry KM, Doi SA, Thalib L. Screening for diabetes in Kuwait and evaluation of risk scores. East Mediterr Health J. 2010 Jul;16(7):725-31. PMID:20799528
116. Abdella N, Khogali M, al-Ali S, Gumaa K, Bajaj J. Known type 2 diabetes mellitus among the Kuwaiti population. A prevalence study. Acta Diabetol. 1996 Jul;33(2):145-9. PMID:8870817

117. Moussa MA, Alsaeid M, Abdella N, Refai TM, Al-Sheikh N, GomezJE. Prevalence of type 2 diabetes mellitus among Kuwaiti children and adolescents. Med Princ Pract. 2008;17(4):270-5. PMID:18523392

118. Naja F, Hwalla N, Itani L, Salem M, Azar ST, Zeidan MN, et al. Dietary patterns and odds of Type 2 diabetes in Beirut, Lebanon: a case-control study. Nutr Metab (Lond). 2012;9(1):111. PMID:23270372

119. Ghassibe-Sabbagh M, Deeb M, Salloum AK, Mouzaya F, Haber $\mathrm{M}, \mathrm{Al}$-Sarraj Y, et al. Multivariate epidemiologic analysis of type 2 diabetes mellitus risks in the Lebanese population. Diabetol Metab Syndr. 2014;6(1):89. PMID:25191526

120. Kadiki OA, Roaeid RB. Prevalence of diabetes mellitus and impaired glucose tolerance in Benghazi Libya. Diabetes Metab. 2001 Dec;27(6):647-54. PMID:11852372

121. Rguibi M, Belahsen R. Prevalence and associated risk factors of undiagnosed diabetes among adult Moroccan Sahraoui women. Public Health Nutr. 2006 Sep;9(6):722-7. PMID:16925877

122. Al-Moosa S, Allin S, Jemiai N, Al-Lawati J, Mossialos E. Diabetes and urbanization in the Omani population: an analysis of national survey data. Popul Health Metr. 2006;4:5. PMID:16635266

123. Abdul-Rahim HF, Husseini A, Giacaman R, Jervell J, Bjertness E. Diabetes mellitus in an urban Palestinian population: prevalence and associated factors. East Mediterr Health J. 2001 JanMar;7(1-2):67-78. PMID:12596954

124. Yassin MM, Altibi HI, Elshanti AF. Clinical and biochemical features of type 2 diabetic patients in Gaza Governorate, Gaza Strip. West Afr J Med. 2011 Jan-Feb;30(1):51-6. PMID:21863590

125. Bener A, Zirie M, Janahi IM, Al-Hamaq AO, Musallam M, Wareham NJ. Prevalence of diagnosed and undiagnosed diabetes mellitus and its risk factors in a population-based study of Qatar. Diabetes Res Clin Pract. 2009 Apr;84(1):99-106. PMID:19261345

126. Bacchus RA, Bell JL, Madkour M, Kilshaw B. The prevalence of diabetes mellitus in male Saudi Arabs. Diabetologia. 1982 Oct;23(4):330-2. PMID:7141167

127. Al-Nuaim AR. Prevalence of glucose intolerance in urban and rural communities in Saudi Arabia. Diabet Med. 1997 Jul:14(7):595-602. PMID:9223399

128. Al-Nozha MM, Al-Maatouq MA, Al-Mazrou YY, Al-Harthi SS, Arafah MR, Khalil MZ, et al. Diabetes mellitus in Saudi Arabia. Saudi Med J. 2004 Nov;25(11):1603-10. PMID:15573186

129. Al-Rubeaan K, Al-Manaa HA, Khoja TA, Ahmad NA, Al-Sharqawi $\mathrm{AH}$, Siddiqui $\mathrm{K}$, et al. Epidemiology of abnormal glucose metabolism in a country facing its epidemic: SAUDI-DM study. J J Diabetes. 2014 Sep 30. doi: 10.1111/1753-0407.12224. PMID:25266306

130. Rahman Al-Nuaim A. Effect of overweight and obesity on glucose intolerance and dyslipidemia in Saudi Arabia, epidemiological study. Diabetes Res Clin Pract. 1997 Jun;36(3):181-91. PMID:9237785

131. Fatani HH, Mira SA, el-Zubier AG. Prevalence of diabetes mellitus in rural Saudi Arabia. Diabetes Care. 1987 MarApr;10(2):180-3. PMID:3582078

132. Almajwal AM, Al-Baghli NA, Batterham MJ, Williams PG, AlTurki KA, Al-Ghamdi AJ. Performance of body mass index in predicting diabetes and hypertension in the Eastern Province of Saudi Arabia. Ann Saudi Med. 2009 Nov-Dec;29(6):437-45. PMID:19847080

133. Al-Agha A, Ocheltree A, Shata N. Prevalence of hyperinsulinism, type 2 diabetes mellitus and metabolic syndrome among 
Saudi overweight and obese pediatric patients. Minerva Pediatr. 2012 Dec;64(6):623-31. PMID:23108324

134. Elbagir MN, Eltom MA, Elmahadi EM, Kadam IM, Berne C. A population-based study of the prevalence of diabetes and impaired glucose tolerance in adults in northern Sudan. Diabetes Care. 1996 Oct;19(10):1126-8. PMID:8886561

135. Albache N, Al Ali R, Rastam S, Fouad FM, Mzayek F, Maziak W. Epidemiology of Type 2 diabetes mellitus in Aleppo, Syria. J Diabetes. 2010 Jun;2(2):85-91. PMID:20923489

136. Bouguerra R, Alberti H, Salem LB, Rayana CB, Atti JE, Gaigi S, et al. The global diabetes pandemic: the Tunisian experience. Eur J Clin Nutr. 2007 Feb;61(2):160-5. PMID:16900086

137. Al-Habori M, Al-Mamari M, Al-Meeri A. Type II diabetes mellitus and impaired glucose tolerance in Yemen: prevalence, associated metabolic changes and risk factors. Diabetes Res Clin Pract. 2004 Sep;65(3):275-81. PMID:15331208

138. Gunaid AA, Assabri AM. Prevalence of type 2 diabetes and other cardiovascular risk factors in a semirural area in Yemen. East Mediterr Health J. 2008 Jan-Feb;14(1):42-56. PMID:18557451

139. Al-Sharafi BA, Gunaid AA. Prevalence of obesity in patients with type 2 diabetes mellitus in yemen. Int J Endocrinol Metab. 2014 Apr;12(2):el3633. PMID:24748890
140. Trujillo ME, Scherer PE. Adiponectin-journey from an adipocyte secretory protein to biomarker of the metabolic syndrome. J Intern Med. 2005 Feb;257(2):167-75. PMID:15656875

141. Rabe K, Lehrke M, Parhofer KG, Broedl UC. Adipokines and insulin resistance. Mol Med. 2008 Nov-Dec;14(11-12):741-51. PMID:19009016

142. Antuna-Puente B, Feve B, Fellahi S, Bastard JP. Adipokines: the missing link between insulin resistance and obesity. Diabetes Metab. 2008 Feb;34(1):2-11. PMID:18093861

143. Kahn SE. Clinical review 135: The importance of beta-cell failure in the development and progression of type 2 diabetes. J Clin Endocrinol Metab. 2001 Sep;86(9):4047-58. PMID:11549624

144. Jaikanth C, Gurumurthy P, Cherian KM, Indhumathi T. Emergence of omentin as a pleiotropic adipocytokine. Exp Clin Endocrinol Diabetes. 2013 Jul;121(7):377-83. PMID:23839538

145. Norseen J, Hosooka T, Hammarstedt A, Yore MM, Kant S, Aryal $\mathrm{P}$, et al. Retinol-binding protein 4 inhibits insulin signaling in adipocytes by inducing proinflammatory cytokines in macrophages through a c-Jun $\mathrm{N}$-terminal kinase- and toll-like receptor 4-dependent and retinol-independent mechanism. Mol Cell Biol. 2012 May;32(10):2010-9. PMID:22431523 